\title{
Evolution in the Russian Gas Market - The Competition for Customers
}

\author{
James Henderson
}

NG 73

January 2013 
The contents of this paper are the author's sole responsibility. They do not necessarily represent the views of the Oxford Institute for Energy Studies, of any of the Institute's members, and/or of the author's other affiliations.

Copyright (C) 2013

Oxford Institute for Energy Studies

(Registered Charity, No. 286084)

This publication may be reproduced in part for educational or non-profit purposes without special permission from the copyright holder, provided acknowledgment of the source is made. No use of this publication may be made for resale or for any other commercial purpose whatsoever without prior permission in writing from the Oxford Institute for Energy Studies.

ISBN 978-1-907555-66-4 


\section{Abbreviations and Units of Measurement}

$\begin{array}{ll}\text { bbls } & \text { Barrels } \\ \text { bcm } & \text { Billion cubic metres } \\ \text { bcma } & \text { Billion cubic metres per annum } \\ \text { bn bbls } & \text { Billion barrels } \\ \text { boepd } & \text { Barrels of oil equivalent per day } \\ \text { bpd } & \text { Barrels per day } \\ \text { E\&P } & \text { Exploration and Production } \\ \text { ESPO } & \text { East Siberia - Pacific Ocean (Pipeline) } \\ \text { FSU } & \text { Former Soviet Union } \\ \text { IOC } & \text { International Oil Company } \\ \text { kboepd } & \text { Thousands of barrels of oil equivalent per day } \\ \text { kbpd } & \text { Thousands of barrels per day } \\ \text { km } & \text { Kilometres } \\ \text { mm bbls } & \text { Million barrels } \\ \text { mcm } & \text { Thousands of cubic metres } \\ \text { mmboepd } & \text { Millions of barrels of oil equivalent per day] } \\ \text { mmbpd } & \text { Millions of barrels per day } \\ \text { mmbtu } & \text { Million British thermal units } \\ \text { mmcm } & \text { Millions of cubic metres } \\ \text { mmt } & \text { Millions of tonnes } \\ \text { mmtpa } & \text { Millions of tonnes per annum } \\ \text { Mm tonnes } & \text { Millions of tonnes } \\ \text { P\&P } & \text { Proved and Probable } \\ \text { tcm } & \text { Trillion cubic metres }\end{array}$

\section{Conversion Factors}

\begin{tabular}{|clcl|}
\hline \multicolumn{3}{c|}{ Equals } \\
\hline 1 & tonne oil & 7.3 & barrels of oil equivalent \\
1 & tonne condensate & 8.0 & barrels of oil equivalent \\
& & & \\
1 & bcm gas & 6.6 & mm barrels of oil equivalent \\
1 & bcm gas & 35.3 & billion cubic feet of gas \\
1 & bcm gas & 0.9 & mm tonnes of oil equivalent \\
\hline
\end{tabular}

Source: BP Statistical Review 


\section{Acknowledgements}

This Working Paper is based on a paper delivered at the New Actors in Russian Energy/ Energy Workshop, in Oslo on 11-13 December 2012, organised by the Fridtjof Nansen Institute/ RUSSCASP and the Aleksanteri Institute Center of Excellence on Russian Modernization. Their support is gratefully acknowledged.

I would also like to thank my colleagues at the OIES for their help with this research. In particular I am very grateful for the support and comments provided by Jonathan Stern, Howard Rogers and Simon Pirani, whose contributions were all vital to the completion of my analysis. I would also like to thank my editor, John Elkins, for his detailed corrections and useful comments.

Furthermore I would like to acknowledge the contribution of my colleagues at Lambert Energy Advisory, who as always have been generous with their time and support.

Thanks also to the many industry executives, consultants and analysts with whom I have discussed this topic, but as always the results of the analysis remain entirely my responsibility. 


\section{Preface}

As the world's largest holder of natural gas reserves Russia holds a constant fascination for observers of gas markets; whether the focus is on supply-demand fundamentals or geopolitics. This said there is a tendency to make simplifying assumptions as to the roles and behaviours of key players, the extent of their influence and the 'rules of the game' in general. This paper by James Henderson is a timely reminder that the Russian natural gas supply situation is anything but static.

The non-Gazprom Russian Gas Producers have demonstrated robust production growth over the past few years. While Gazprom has generally been focussed on bringing on-stream giant, but more remote fields, from Bovanenkovskoye on the Yamal peninsula and from Shtokman (postponed during 2012), it has seen the market for these relatively high cost base supplies at best static in Europe and shrinking within Russia as others gain market share. While rising Russian domestic gas prices aid Gazprom, they also provide a strong incentive for its competitors.

James develops this thesis with a wealth of analysis and insight based on his long experience of the sector. Given such pressures on Russia's premier gas producing company described here, the reader is left with the distinct impression that a strategic shift in its business focus will become somewhat inevitable over the next few years.

Howard Rogers 


\section{Contents}

Abbreviations and Units of Measurement .......................................................................... iii

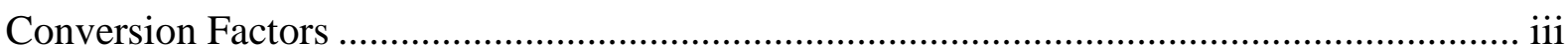

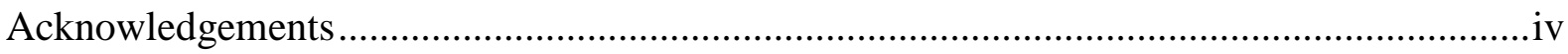

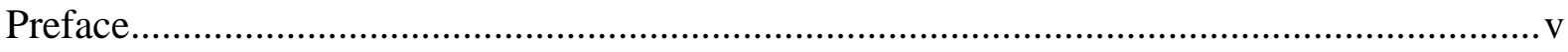

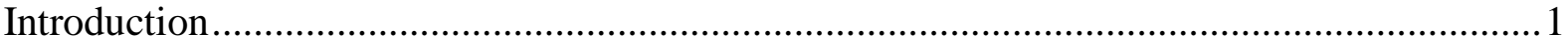

1. Potential Oversupply of Gas in Russia Suggests that Competition is Inevitable ..................1

2. NGP Gas Resources and Potential Output.................................................................... 6

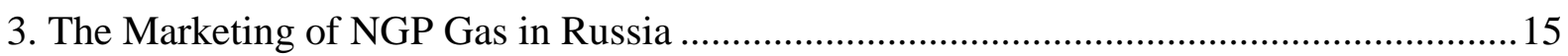

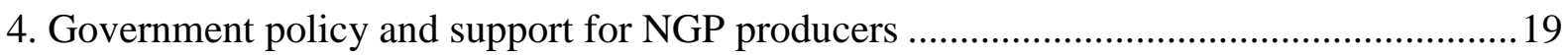

5. A series of long-term contracts has been signed in 2012 .................................................24

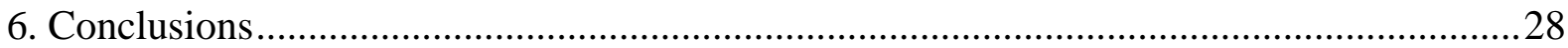

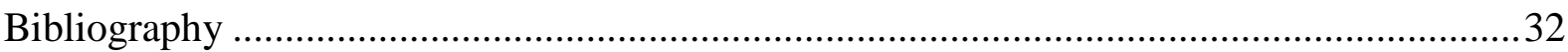

\section{Figures and Tables}

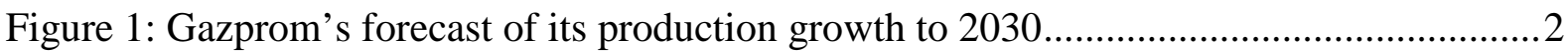

Figure 2: Novatek Forecast of Russian gas production to 2020 ............................................

Figure 3: Estimates of demand for Russian gas in 2020 ..................................................4

Figure 4: Potential production in 2020 from Gazprom and NGPs in Russia under various

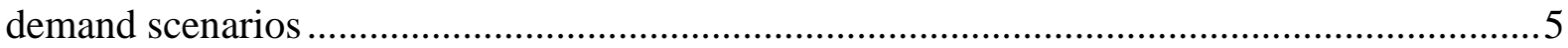

Figure 5: Novatek's gas and liquids production and revenue contributions...........................

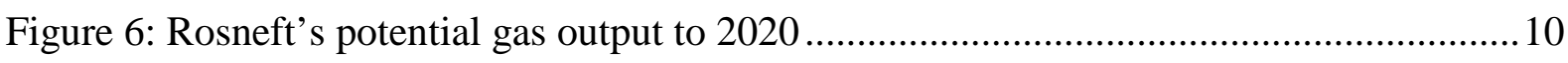

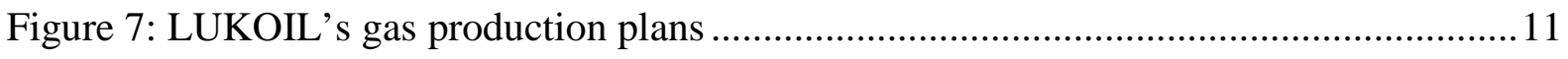

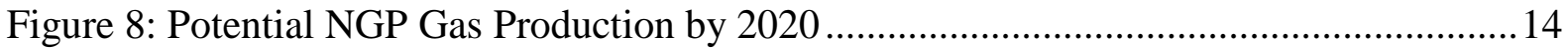

Figure 9: Novatek sales price to End Consumers in Russia compared to Gazprom sales price

Figure 10: Novatek’s EBITDA and Net Profit Margins (2008-2011).................................. 18

Figure 11: Share of NGP output in Russia’s gas production .................................................19

Table 1: NGP gas contracts with domestic Russian consumers ...........................................25 


\section{Introduction}

Throughout the Post-Soviet era Gazprom has been the dominant force in the Russian gas market and the prices which it can charge domestic customers have been regulated by a variety of state bodies, the latest being the Federal Tariff Service. Prices have historically been very low, at times even below the cost of production, but over the past decade a concerted effort has been made under the Putin Administration to increase the domestic gas price towards the export price (netted back to Russia) that Gazprom charges to its European customers. As a result of this price increase and the resultant improvement in the economics of gas sales in Russia a number of new entrants have been attracted to the market place, including “independent” gas producers such as Novatek and oil companies such as Rosneft, TNK-BP and LUKOIL who have gas reserves that they wish to monetise. To date these new entrants have been reluctant to challenge the state-owned quasi-monopoly player, in particular because Gazprom owns the vital trunk pipeline system and has therefore had control of access to domestic customers. However, this reticence from Gazprom's potential rivals now appears to be changing and could herald a fundamental shift in the competitive landscape in the Russian gas sector.

\section{Potential Oversupply of Gas in Russia Suggests that Competition is Inevitable}

In her paper “Russian Gas Reform Under Putin III” Loe (2012) identifies that the debate over potential reform in the Russian gas sector has been continuing for a decade or more, with a focus on the "need for fundamental restructuring of the gas sector...[as] only with restructuring and liberalisation will the Russian gas sector become more efficient”. However, she then goes on to point out that many of the actors within the companies involved in the Russian gas industry view talk of reform as one of "the issues that are being raised by outsiders rather than what is being considered internally", with one being quoted as stating that "nobody talks about structural reform here.” This suggests that there is little appetite for radical change, with the status quo involving Gazprom dominance domestically and as Russia’s sole gas exporter expected to remain in place for many years to come.

However, as this paper will discuss, significant change is occurring in the Russian gas sector, catalysed both by the political decision to increase gas prices and by the consequent reaction of a set of Non-Gazprom Producers (NGPs) who are now starting to exploit the opportunity to sell their product at negotiated prices and contract terms directly to Russian consumers 
who are increasingly keen to find alternative sources of supply. Although many of the NGPs do not like to describe themselves as competitors of Gazprom, no doubt fearing a political backlash from the Kremlin or a strong response from the state-owned company which clearly remains the largest player in the sector, it is nevertheless the case that an increasingly competitive market place is emerging and that a number of companies are developing strategies to exploit this new situation. When this state of affairs is combined with the fact that, as identified recently by both Pirani (2011) and Maximov (2012), gas demand growth in Russia is likely to slow in response to higher prices and the government's calls for greater energy efficiency, the logical conclusion would appear to be that the competition to sell gas in Russia could be quite intense, with Gazprom not necessarily being the obvious winner.

The extent of the potential competition is highlighted by two graphs presented by Russia's largest gas producers, Gazprom and Novatek, within the past six months. The first, shown by Gazprom at its Strategy Day in February 2012 (Gazprom, 2012b), shows the company's forecast production to 2030, with output reaching 660bcm in 2020 and $775 \mathrm{bcm}$ in 2030. As can be seen from Figure 1, the widely acknowledged decline in Gazprom's existing fields, in particular the three giants Urengoy, Yamburg and Medvezhye, is more than compensated by the growth in output from new fields in Nadym Pur Taz (NPT) in West Siberia, the Yamal Peninsula, the Shtokman field in the Barents Sea and the East of Russia.

\section{Figure 1: Gazprom's forecast of its production growth to 2030}

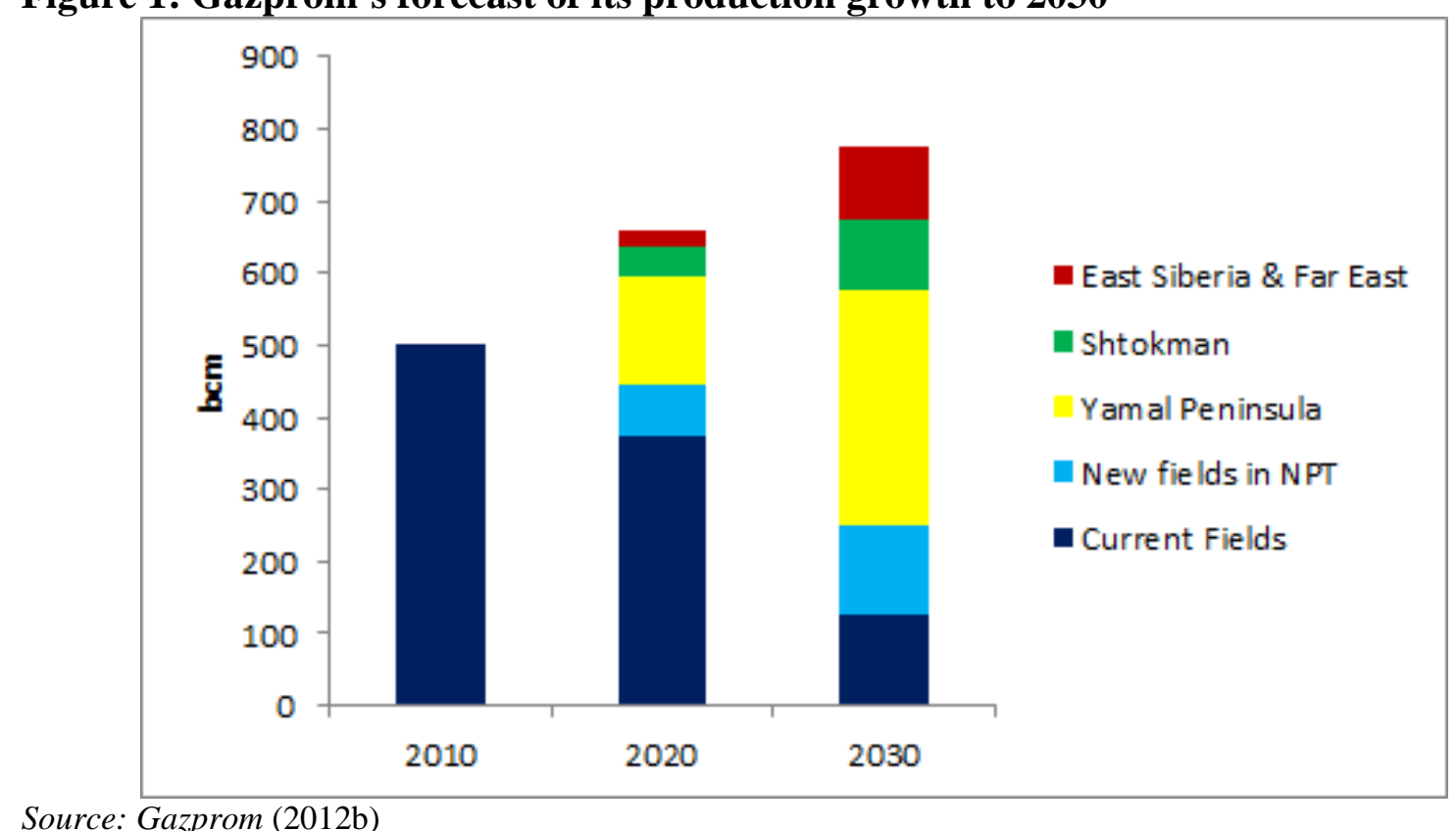

The second graph, which is an extrapolation from a forecast shown most recently by Novatek in a presentation to investors in September 2012 (Novatek, 2012a, p. 21), shows a view of 
future Russian gas supply which offers a very different outcome for Gazprom and demonstrates the impact that NGPs could have in the current decade. Essentially it forecasts total demand for Russian gas in 2020 of $882 \mathrm{bcm}$, which will be supplied by Gazprom, NGPs and imports from Central Asia. However, as is clearly evident from the red bar in Figure 2, the outcome for Gazprom is radically different from that shown in Figure 1, as its production is estimated to only reach 540bcm by 2020 or $120 \mathrm{bcm}$ less than Gazprom's own plan. The clear inherent conflict between these two forecasts highlights the potential for competition between suppliers of Russian gas to secure customers for their output.

\section{Figure 2: Novatek Forecast of Russian gas production to 2020}

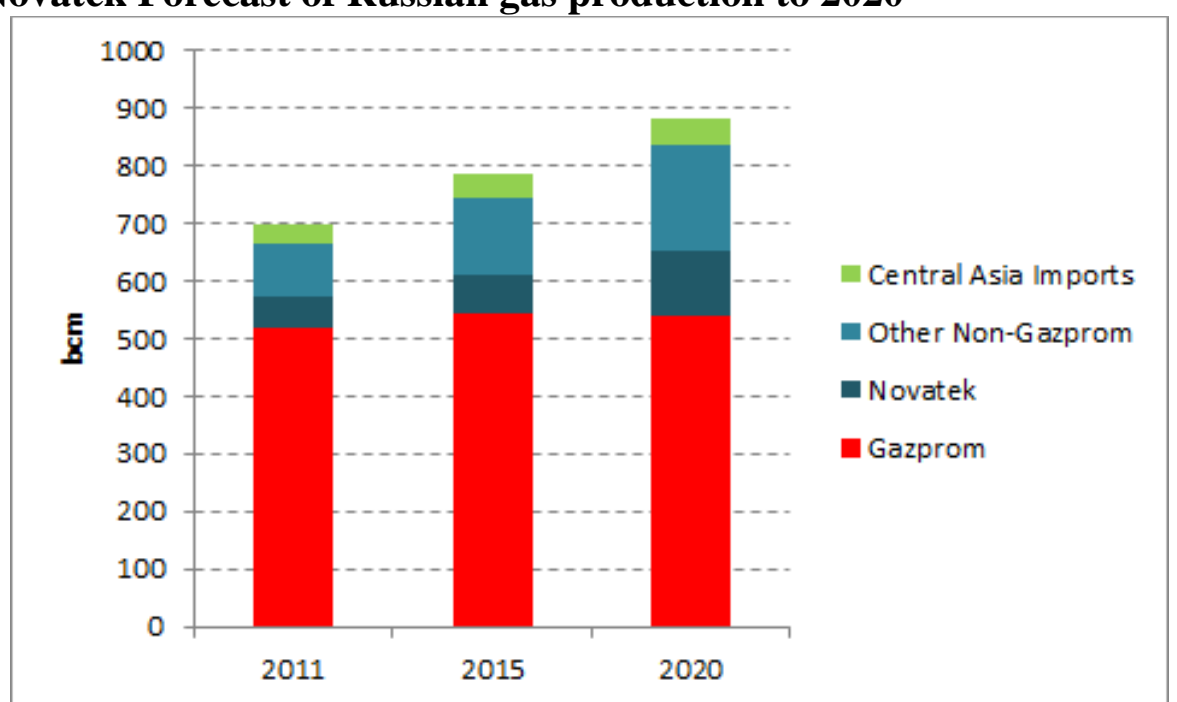

Source: Author's calculation from data provided by Novatek during a presentation in September 2012 (Novatek, 2012a)

The probability of change in the market seems even more likely if one considers the outlook for demand from those customers. The IEA World Energy Outlook for 2011 (IEA, 2011) provided a detailed analysis of the Russian energy economy, including a series of forecasts for gas demand, and I have used these to create the base, high and low scenarios shown in Figure 3. ${ }^{1}$ As can be seen in the graph, the base case demand figure for 2020 is almost exactly $100 \mathrm{bcm}$ below the figure used by Novatek while even the high case figure is 25bcm lower, suggesting immediately that the competition for gas demand could be more intense than initially suggested. Figure 3 includes gas demand from Europe (including the CIS) of between 210-240bcm, with exports to China ranging from zero to 38bcm and LNG exports between $10 \mathrm{bcm}$ and $35 \mathrm{bcm}$. But of course the largest component of demand is domestic, which is seen remaining almost flat at 2010 levels in the low case scenario, rising by 1\% per

\footnotetext{
${ }^{1}$ IEA data has been translated into volumetric figures equivalent to those used by Russian gas companies. A conversion factor of 1 Russian bcm $=0.82$ Mtoe has been used, and all IEA gas volumes quoted in bcm have been multiplied by 1.017 to reflect the Russian equivalent.
} 
annum to reach $480 \mathrm{bcm}$ in the base case and rising by $1.3 \%$ per annum to reach just below $500 \mathrm{bcm}$ in the high case.

\section{Figure 3: Estimates of demand for Russian gas in 2020}

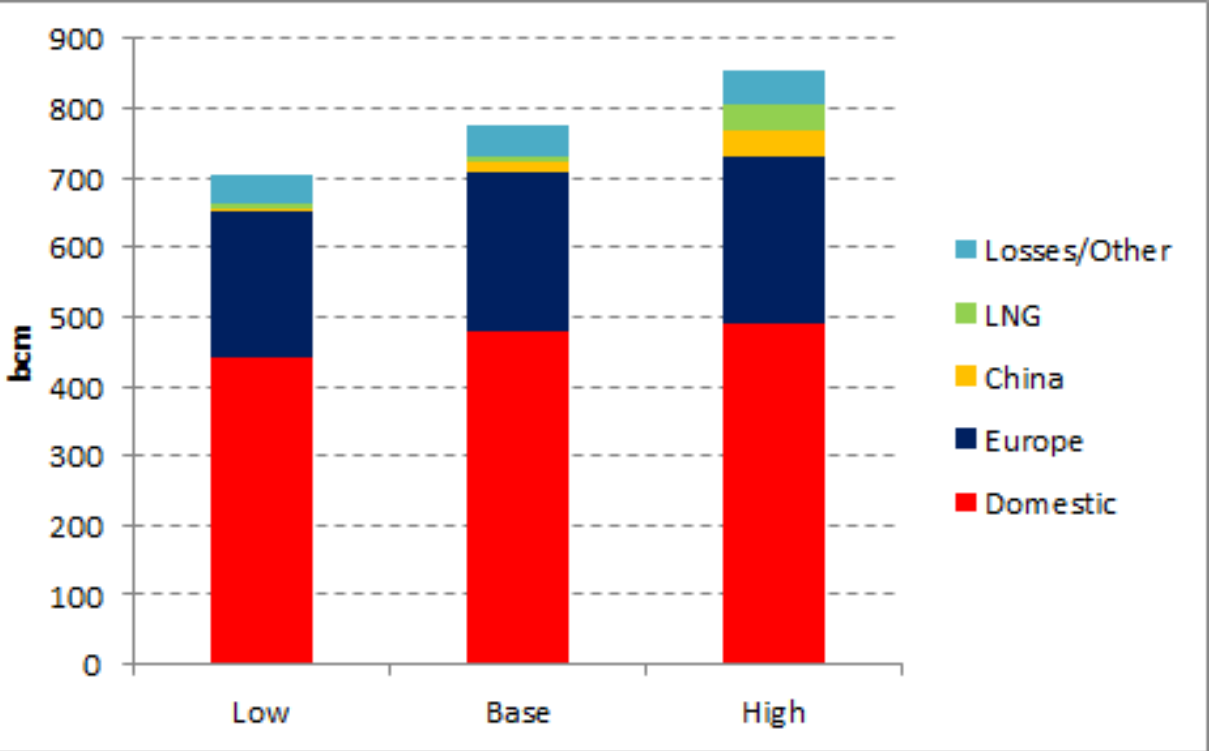

Source: Author's interpretation of data from IEA World Energy Outlook 2011

Unfortunately for Russian gas producers, the likelihood of the low case scenario becoming a reality cannot be dismissed lightly, as the government targets for increased energy efficiency could imply, if fully implemented, a potential saving of around $160 \mathrm{bcma} .^{2}$ Although this is of course unlikely to be achieved in full, and would be partially offset by GDP growth and increased gasification (in the Russian East, for example), nevertheless the prospect of the growth in the demand for Russian gas demand stalling or even going into reverse must be a real possibility as gas prices rise and capital stock replacement in energy intensive industries starts to occur.

A final conclusion about the potential for competition amongst Russian gas suppliers can therefore be drawn by combining the demand and potential supply analysis together. Figure 4 shows two scenarios, and although they offer the most radical "bookends" of the analysis they can nevertheless provide a useful indication of the potential scope of the issues facing Russian gas producers.

\footnotetext{
${ }^{2}$ Estimate from IEA World Energy Outlook 2011, p.260
} 
Figure 4: Potential production in 2020 from Gazprom and NGPs in Russia under various demand scenarios

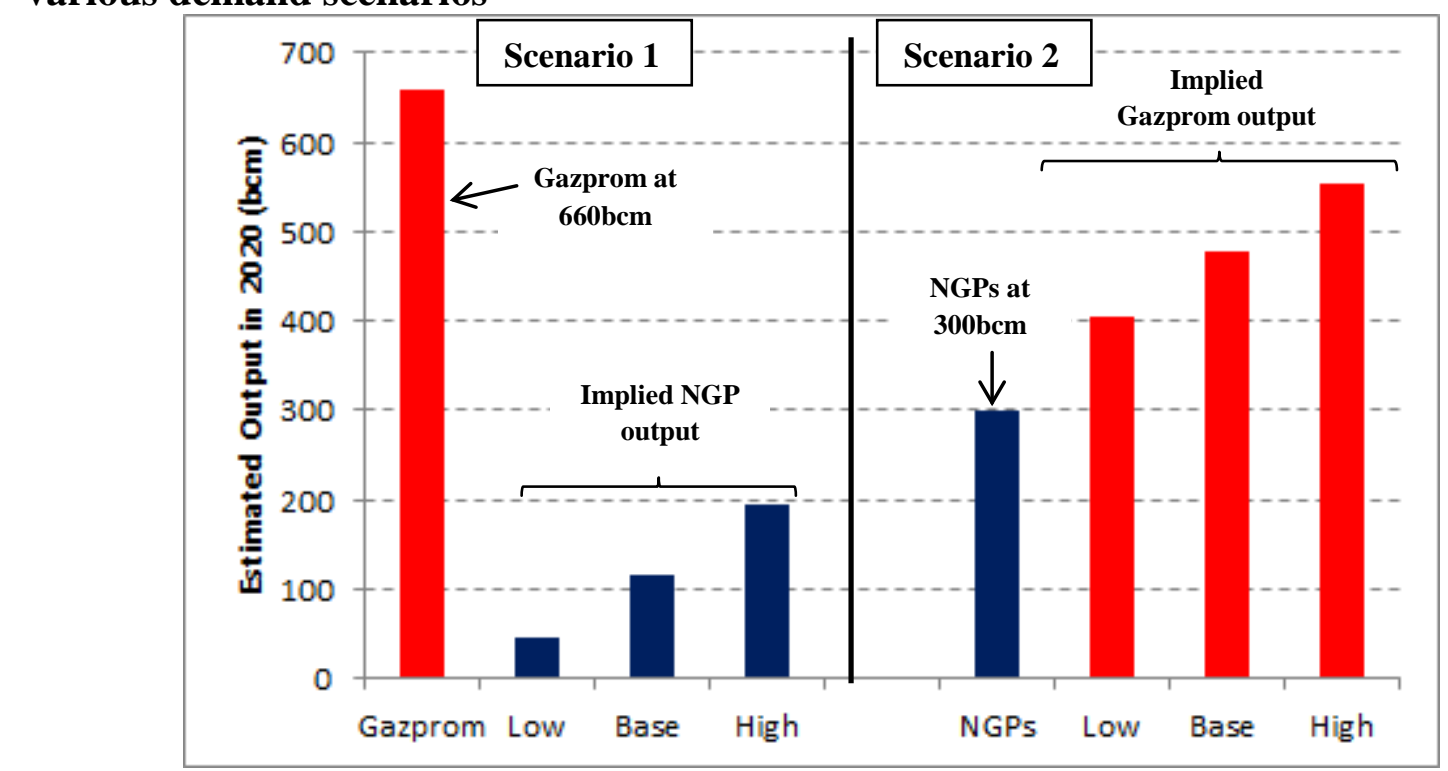

Source: Author's calculation based on IEA and Company Data

Scenario 1 assumes that Gazprom achieves its output target of 660bcm by 2020, and then (in the blue bars) estimates the impact on NGP gas production in the low, base and high case demand scenarios. As can be seen, in the base case scenario output is approximately $120 \mathrm{bcm}$, 40bcm below the level seen in 2011; in the low case it would collapse to below $50 \mathrm{bcm}$ (implying that in reality only associated gas would be produced); while even in the high case NGP output would only reach $195 \mathrm{bcm}$, more than $100 \mathrm{bcm}$ below Novatek's assessment of the potential outcome. Scenario 2 then assumes that the Novatek target of 300bcm of NGP output is met by 2020 and assesses the implications for Gazprom. In the base demand case Gazprom output would fall from the 2011 level of 515bcm to approximately 475bcm, which interestingly is close to the level seen in 2009 at the height of the economic crisis when Gazprom produced $462 \mathrm{bcm}$. In the high demand scenario Gazprom output can increase to $555 \mathrm{bcm}$, or back to the levels seen throughout most of the 2000s (Interfax, 2012, p. 36). However, in the low demand scenario Gazprom's production could collapse to only $400 \mathrm{bcm}$ if it bears the brunt of fierce competition for demand from increasingly efficient gas consumers in Russia while also suffering from lower demand in the export market.

It is clearly unrealistic to expect that any one of these scenarios will play out exactly as described, with the outcome likely to a hybrid, but the analysis does highlight the potential for a dramatic change in the psychology of the Russian gas market over the next decade as producers are forced to compete for customers who are likely to become increasingly pricesensitive. In order to understand how likely such a change is, and what real impact NGPs may 
have, a number of key questions need to be answered. The first is whether NGPs have the resources to fulfil the $300 \mathrm{bcm}$ production forecast, and if so at what cost. The second concerns the strategies of the NGPs, and in particular the tactics that they are using to gain market share in Russia and potentially overseas. A third, and vital, issue concerns the response of the Russian government to the emerging changes in the domestic and export markets for the country's gas, and especially whether it sees a need to protect Gazprom's position because of the company's political and economic importance. And finally, the potential reaction of Gazprom also needs to be discussed, as it is certain to remain the single largest gas producer in Russia until 2020 and probably beyond.

\section{NGP Gas Resources and Potential Output}

The NGPs in Russia include a number of sub-groups, namely independent gas producers such as Novatek and Itera, the Russian Oil Companies (ROCs), in particular Rosneft, LUKOIL, TNK-BP and Surgutneftegas, foreign companies who are generally partners of Gazprom or other domestic companies and finally some small regional producers. However, although within these various groups up to 70 individual producers of natural and/or associated gas can be identified (Henderson, 2010, p. 42), only a handful are large enough to merit attention and of those two, Novatek and Rosneft, now stand out as the most likely to have a major impact by 2020 .

\section{Novatek}

Novatek is Russia's second largest gas company, and although it is dwarfed by Gazprom it also ranks in the top five quoted companies in the world on the basis of proved gas reserves. At the end of 2011 Novatek had 1.3tcm of proved gas reserves under the strict SEC definitions, with as much as $2.1 \mathrm{tcm}$ under the PRMS proved plus probable classification, ${ }^{3}$ and importantly also owned approximately 700 million barrels of oil and condensate reserves, the production of which provides a significant boost to the economics of the company's gas output (Novatek, 2012b, p. 5). Novatek’s production in 2011 reached 53.5bcm of gas plus 85,000 bpd of liquids, meaning that the company has a gas reserve life of 24 years under the SEC proved definition and almost 40 years under the more generous proved plus probable definition.

\footnotetext{
${ }^{3}$ PRMS $=$ Petroleum Resources Management System, a reserve classification methodology approved by the Society of Petroleum Engineers
} 
The long reserve life which Novatek enjoys at current production rates emphasizes the potential for output growth from the company, and its most recent plans envisage a doubling of gas production to reach $112.5 \mathrm{bcm}$ by 2020 (Novatek, 2011, p. 32). This growth is based not only on the company's existing reserves but also on the significant resource base that it has built up through the acquisition of new licences, and is especially focussed on new gas fields on the Yamal and Gydan peninsulas where a total of over 2.5tcm of potential gas resources have been identified in four new fields. Although there is clearly some risk attached to the development of these new assets, as well as to the planned exploitation of the South Tambey field that is also located on Yamal, Novatek's track record of doubling production since 2006 and consistently meeting its output targets suggests that from a resource perspective the company is well placed to achieve its $112 \mathrm{bcm}$ goal by 2020 .

Further confidence is provided by the economics of Novatek's business, which as noted above is underpinned by liquids as well as gas reserves. As Figure 5 demonstrates, although liquids production (and most specifically condensate) accounts for less than $10 \%$ of the company's total output it contributes up to $40 \%$ of Novatek's revenues, underpinning its ability to generate very high margins while selling its gas at relatively low domestic prices. ${ }^{4}$ The importance of liquids in Novatek's production portfolio is set to continue, with production forecast by the company to more than triple to 270,000 bpd by 2020 (Novatek, 2011, p. 32), and as a result it is likely that Novatek will be able to continue to offer competitively priced gas to domestic, and possibly to foreign, consumers of Russian gas. The fact that all of the company's main current and future assets are located within a fairly tight geographic area within the Nadym-Pur-Taz and Yamal Nenetsk regions of West Siberia also suggests that Novatek's clear understanding of the geology of the region and its ability to use and build upon existing infrastructure can provide a reliable growth trajectory for the company.

\footnotetext{
${ }^{4}$ In H1 2012 Novatek generated an EBITDA margin of 45\% and a net margin of 31\%
} 
Figure 5: Novatek's gas and liquids production and revenue contributions

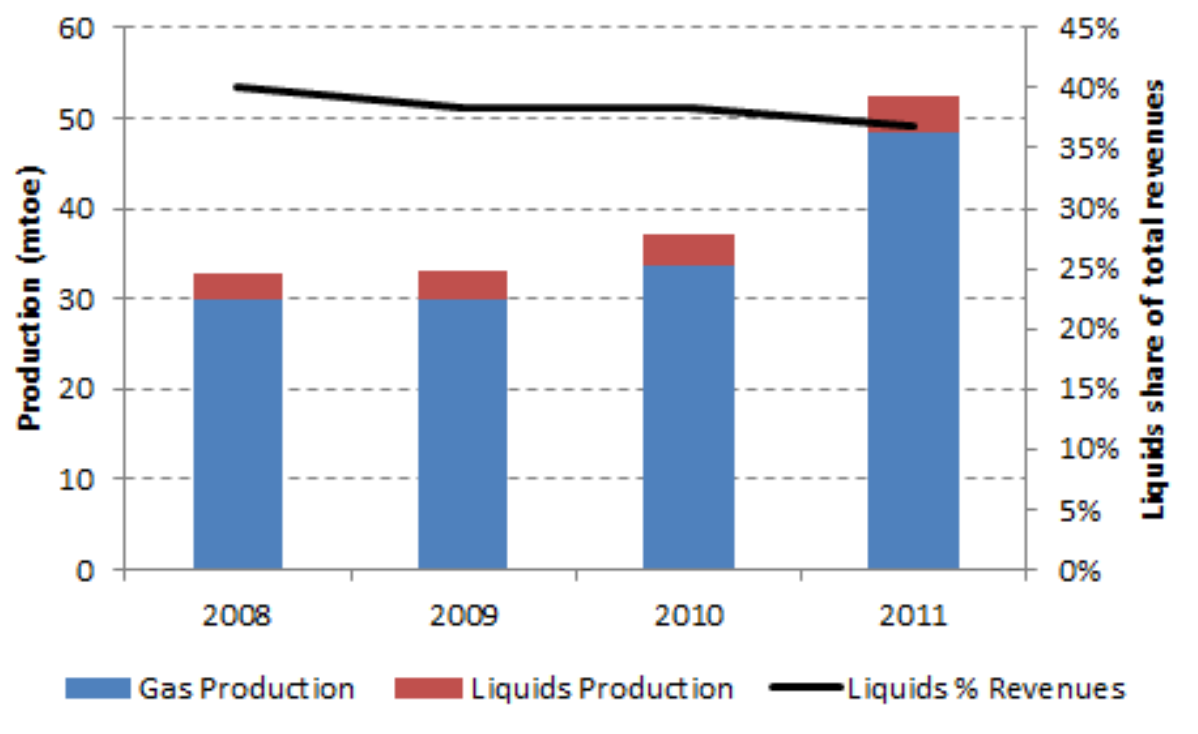

Source: Novatek IFRS Quarterly Results

\section{Rosneft}

Rosneft has had the ambition to develop a significant gas business in Russia since its IPO $^{5}$ in 2005. This ambition has been based upon the fact that the company has $850 \mathrm{bcm}$ of proved gas reserves but only produces 12-13bcma (Rosneft, 2012a), meaning that it has a reserve life of almost 70 years and obvious potential for significantly increased output and sales. Indeed the company's proved and probable reserves, which total $1.25 \mathrm{tcm}$, offer a reserve life of over 100 years. As a result, Rosneft initially announced a target in 2008 to increase its gas production to 55bcm within 10 years (Rosneft, 2008, p. 18), but this goal has consistently been moved back as a result of the company's inability to secure access to sufficient domestic customers. The frustration at this constant delay has been compounded by the fact that much of the company's gas is located in the gas reservoirs of the Kharampur field, which could be easily and cheaply exploited using much of the infrastructure that has already been used to develop the oil layers of the field (Rosneft, 2006, p. 65). However, Rosneft has been unwilling to commit to the investment required to exploit more than $500 \mathrm{bcm}$ of gas reserves at the field that could ultimately produce up to 25bcma until it could establish a commercial market for its output.

In 2012, Rosneft finally took a significant step towards achieving this by forming a joint venture with the ITERA Group to produce and sell gas owned by both companies. ${ }^{6}$ Rosneft

\footnotetext{
${ }^{5}$ Initial Public Offer

${ }^{6}$ Rosneft Press Release, 6 August 2012, “Rosneft and ITERA Group close deal to create Joint Venture to produce and sell gas”, Moscow
} 
has initially contributed non-producing assets (its Kynsko-Chaselskoye Neftegaz subsidiary) plus $\$ 173 \mathrm{~mm}$ of cash in order to take a $51 \%$ stake in the venture that will also include all of ITERA's gas assets, with current output of 13bcma. ITERA's main competitive advantage, however, is not its existing production but its marketing experience, in particular in the Sverdlovsk region (ITERA, 2009, p. 24), and Rosneft will hope to exploit this skill-set as it looks to market not only the gas controlled by the joint venture but also its other portfolio gas (including Kharampur). As will be discussed below, progress in achieving this goal is already being made.

Rosneft further enhanced its position in the Russian gas market in 2012 through the announcement of its purchase of TNK-BP for a combined \$56 billion from BP and AAR. ${ }^{7}$ Assuming that the deal is completed on schedule in early 2013 Rosneft will have acquired not only Russia’s third largest oil producer but also a company that has significant gas production growth ambitions of its own, largely based around its Rospan subsidiary in West Siberia. TNK-BP produced more than 14bcm of gas in 2011 (of which approximately 11bcm was associated gas), but plans to grow this output to over 30bcm by 2020 largely thanks to growth in output from Rospan from 3bcm to $16 \mathrm{bcm}$ over the next five years (TNK-BP, 2012). Rospan is a wet gas field, and so the economics of the gas output are enhanced by associated liquids production similar to Novatek's assets, but production has again been delayed by lack of adequate access to customers over the past decade. However, TNK-BP's active strategy to improve its marketing capability (also discussed below) and the increasing availability of pipeline capacity out of West Siberia has meant that a full field development was approved by the company's board in October $2012^{8}$ and production should start to increase from 2013.

Overall, then, Rosneft appears to have the resource base and increasingly the marketing capability to rapidly increase its sales into the Russian domestic gas market. The company itself has targeted production of $100 \mathrm{bcm}$ as its ultimate goal (Rosneft, 2012b, p. 13), and as shown in Figure 6 this would appear to be eminently achievable before the end of the decade given Rosneft's organic asset base and its recent M\&A activity. Indeed, if the company were to fully exploit the assets now at its disposal it could even challenge Novatek for its position as Russia’s second largest gas producer by 2020.

\footnotetext{
7 Rosneft Investor Presentation, 23 Oct 2012, slide 2 - "Proposed Transaction Terms"

8 TNK-BP press release, 5 Oct 2012, “TNK-BP Board Meeting Results", Cyprus
} 
Figure 6: Rosneft's potential gas output to 2020

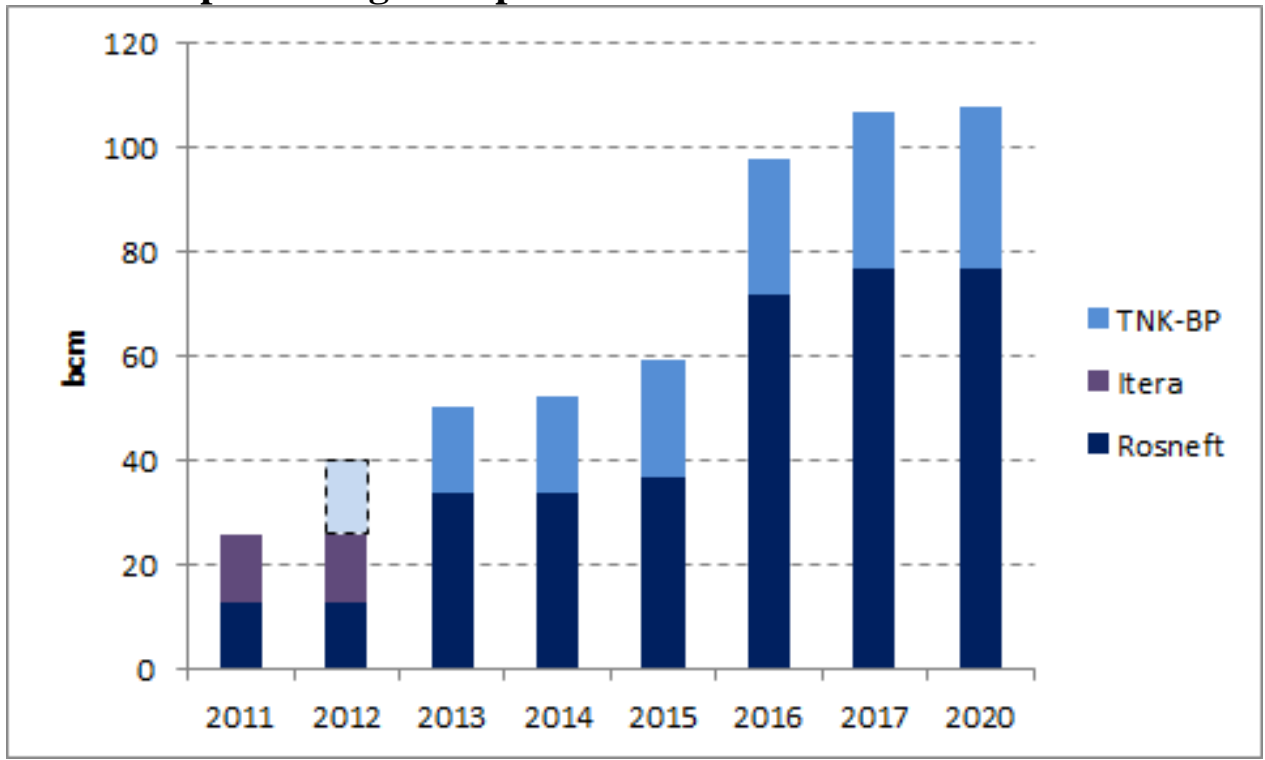

Source: Rosneft (Rosneft, 2012b) and Author's Estimates

\section{Other Non-Gazprom Producers}

Russia's second largest oil company, LUKOIL, also has plans for significant growth in the gas sector, although its strategy is somewhat different from Novatek and Rosneft not only because domestically it has a closer relationship with Gazprom but also because it has chosen to invest in gas assets overseas. However, as will be discussed later, this still makes it a potential competitor in a broadening battle for customers for Russian gas output. Figure 7 shows the company's planned output growth, with the domestic expansion from the 2011 figure of just under $14 \mathrm{bcm}$ to a 2021 target of 34bcm supported by a reserve base located in both West Siberia and the North Caspian regions. LUKOIL has total proved gas reserves in Russia of just under 500bcm (LUKOIL, 2012d), of which the majority are located in the Bolshekhetskaya Depression in West Siberia where the Nakhodkinskaya field accounts for more than $90 \%$ of the company's production from natural gas fields as opposed to associated gas from oil fields. The company’s remaining gas reserves are largely located in West Siberia as associated gas or in the North Caspian, where production from the Yuri Korchagin and Filanovsky fields will supply LUKOIL’s power assets in Southern Russia from 2012. 
Figure 7: LUKOIL's gas production plans

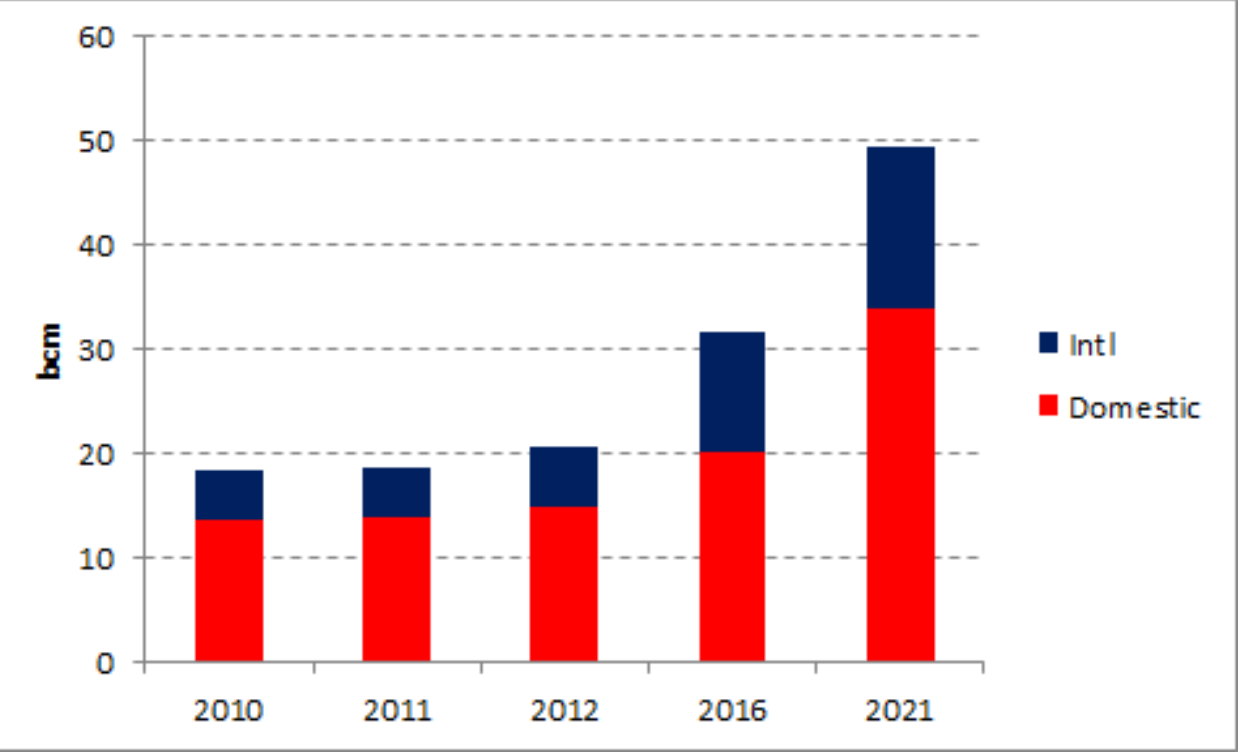

Source: LUKOIL data from various investor presentations

LUKOIL's domestic gas plans seem rather conservative given the total resources at the company's disposal, which amount to almost 1tcm of gas if probable and possible reserves are included. However, the company's approach has been tempered by its strategy to date of selling most of its gas to Gazprom at the wellhead in West Siberia, and indeed it has an agreement to sell up to $12 \mathrm{bcma}$ on this basis from the Nakhodkinskoye field until 2016 (LUKOIL, 2012a, p. 19). Beyond this date production from West Siberia is forecast to increase by 5-10bcm by 2020 as new fields in the Bolshekhetskaya Depression are brought onstream, but a more innovative approach to gas production and marketing has been adopted in southern Russia where LUKOIL's North Caspian gas fields will supply 7-8bcma to the company's power assets (Alekperov, 2011) and a further 2bcma to its petrochemicals complex. As a result LUKOIL has essentially created demand for its own gas through buying power assets (that have to date been supplied by Gazprom) and gradually replacing their fuel input with LUKOIL gas and by developing a new downstream business to enhance the value of its domestic gas chain. Overall it would therefore seem that LUKOIL is certainly capable of increasing its Russian gas production to 40bcm by 2020 (Alekperov, 2012b, p. 23), with the main risk being its exposure to Gazprom as a buyer of third party gas.

Although this paper is mainly concerned with the Russian domestic market, it is nevertheless interesting to note that LUKOIL's international assets, and especially those in the Caspian region, may also have an influence on Russia’s overall gas strategy. In particular, LUKOIL’s strategy to invest in Uzbek gas assets (LUKOIL, 2012b, p. 44), which was taken as a direct result of its frustration in the Russian domestic gas market in the mid-2000s, could soon 
provide a rival source of supply for Gazprom in the Chinese gas market. LUKOIL's gas is set to be exported via the new Central Asian pipeline to Western China while Gazprom has failed to convince $\mathrm{CNPC}^{9}$ to buy its gas via the Altai pipeline and even continues to struggle to reach an export agreement for its potential gas production in East Siberia.

Amongst the other Russian oil companies Surgutneftegaz is the most significant gas producer, with associated gas output of just under 13bcm in 2011 (Interfax, 2012, p. 15) that is mainly sold to local power and industrial companies, although the company is starting to expand the reach of its marketing operations. However, Surgutneftegaz has no specific plans to grow its gas business dramatically, and future gas production will only grow in line with the company's oil output. In contrast GazpromNeft has shown significant growth in gas production and sales over the past two years as it has not only optimised is associated gas output but has brought a number of natural gas projects onstream. In particular the development of the Muravlenskoye and Novogodneye fields has seen overall company gas output jump from 4bcm in 2010 to $9 \mathrm{bcm}$ in $2011^{10}$ (including the company's interests in Slavneft and Tomskneft), and with the development of the Severenergia JV with Novatek, ENI and Enel production output should continue to rise slowly over the next few years (Gazprom Neft, 2011, p. 13).

The most significant remaining NGP producers are the Sakhalin projects in the Far East. Sakhalin 1 produces almost $9 \mathrm{bcma},{ }^{11}$ and although the majority of this is re-injected at present, the finalisation of a sales agreement between Exxon and Gazprom could see the gas arrive on the domestic and/or export markets in the next few years. Meanwhile Sakhalin 2 produces more than 16bcma, ${ }^{12}$ all of which is exported as LNG. The potential for an expansion of the LNG project via the addition of a third train is being actively discussed, which could be initially filled with extra Sakhalin 2 gas before being supplied by the new Sakhalin 3 project in the medium to long-term.

Much of the remaining NGP gas is associated with oil production, but there are a few specific gas companies and projects that are worth noting. The Severenergia joint venture mentioned above has the potential to produce as much as 36bcma of gas plus associated condensate by 2017 (Novatek, 2011), and will make the Enineftegas JV between ENI and Enel one of the

\footnotetext{
${ }^{9}$ China National Petroleum Corporation

${ }^{10}$ http://ir.gazprom-neft.com/key-operational-data/production, sourced 5 Nov 2012

${ }^{11}$ Production data from Interfax, reporting 2011 totals produced by the Fuel and Energy Complex Central Dispatch Department

${ }^{12}$ Ibid
} 
largest foreign gas producers in Russia with net output of 18bcma. Total of France will also be increasing its presence in Russian gas supply via its two joint ventures with Novatek at the Yamal LNG project (20\% Total) and the smaller Termokarstovoye field (Novatek, 2012b, p. 3), which could provide combined net production of 6bcma by 2020. Meanwhile the German companies Wintershall and E.On also have significant gas assets in Russia, both being joint partners with Gazprom at the 25bcma South Russkoye field, while Wintershall also has a 49\% interest in the deep gas condensate Achimgaz project with Gazprom (Gazprom, 2012a, pp. 100-102). The final major project with foreign participation is the Shtokman field in the Barents Sea, where Total and Statoil remain in negotiations with Gazprom about the ultimate development schedule for the field, although it now seems unlikely that first production will occur until after 2020 (Gazprom, 2012a, p. 104).

Four other domestic producers are worth noting. North Gas, which is a company that is now jointly owned by Novatek (49\%) and Gazprom (51\%), following Novatek’s recent purchase of the shares previously owned by the little known private company REDI, ${ }^{13}$ currently produces a gross 3-4bcma from the North Urengoy field, although this could be increased to almost 15bcma if a full development plan could be agreed (Henderson, 2010, p. 106). Meanwhile Norilskgazprom and Taimygaz jointly supply 3-4bcma of gas to the Norilsk region, and in particular the Norilsk Nickel mining complex, while Yakutgazprom sells 1.5bcma in the region of Sakha, although these last three producers are not connected to the main trunk pipeline system and their output will almost certainly remain flat for the foreseeable future (Henderson, 2010).

Overall, then, the future growth in NGP output in Russia will be driven by two major sources, Novatek and Rosneft (including TNK-BP and the JV with Itera), with the remainder of the current NGP producers contributing small potential increases over the next five to ten years (see Figure 8). One more general source of oil company gas production that has not been mentioned above is a reduction in gas flaring, where the potential for savings ranges from 1550bcma, ${ }^{14}$ and in the graph below I have made the generic assumption that approximately 20bcm of extra savings can be made by 2020 and is spread across the various oil producers. With this inclusion it would seem that the potential for NGP gas production by 2020 is as

\footnotetext{
${ }^{13}$ Novatek press release, 9 Nov 2012, “Novatek Board of Directors approve transaction”, Moscow

${ }^{14}$ Estimates of gas flaring in Russia vary significantly, from $13 \mathrm{bcm}$ estimated by the Russian authorities to 36bcm estimated by PFC Energy in its 2007 report “Using Russia’s Associated Gas” and finally to the 48bcm estimated by the NOAA (National Oceanic and Atmospheric Association) for the World Bank Global Gas Flaring Reduction Partnership in 2010
} 
high as $350 \mathrm{bcm}$, providing credibility to the Novatek estimate of $300 \mathrm{bcm}$ of NGP gas sales by that date. However, the fact that this potential exists clearly does not mean that it will necessarily be realised, in particular because Gazprom has now brought the Bovanenkovskoye field on the Yamal peninsula into production, with its potential output of 115bcm by $2017 .{ }^{15}$ As a result it is clear that if NGP producers are to fulfil their gas sales potential they will have to compete aggressively to find their place in the overall market for Russian gas, and the next section discusses how they are starting to achieve this goal through the more active marketing of their gas to end consumers.

Figure 8: Potential NGP Gas Production by 2020

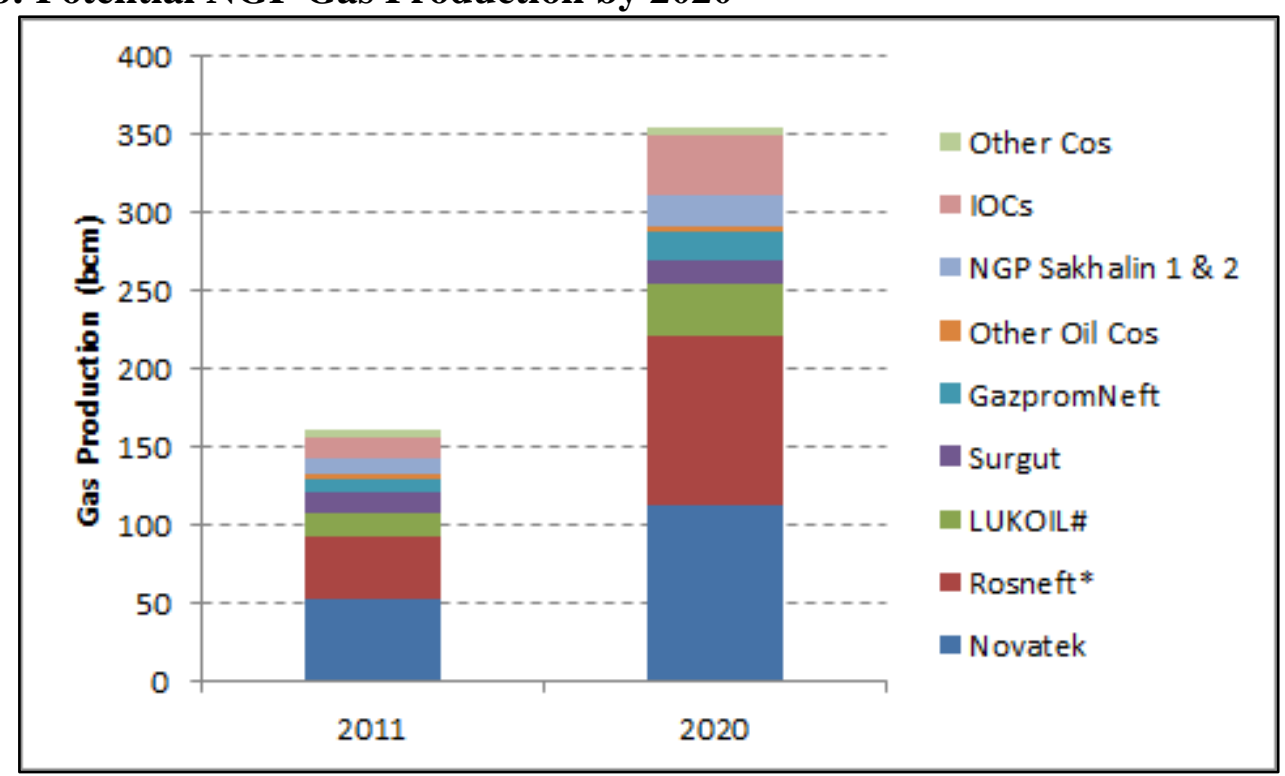

Source: Author's estimates based on Company Data (* Rosneft data includes JV with Itera and assumes acquisition of TNK-BP; \# LUKOIL data includes Russian assets only; Sakhalin 1\&2 figures exclude Gazprom's interest in production)

${ }^{15}$ Gazprom press release, 23 Oct 2012, “Commercial gas production launched in Yamal peninsula”, Moscow 


\section{The Marketing of NGP Gas in Russia}

Historically the marketing of gas in Russia has been dominated by Gazprom for a number of key reasons. Firstly, and most obviously, it is the owner of the trunk pipeline system (the Unified Gas Supply System or UGSS) that is the route to all major gas consumers in Russia. Although Third Party Access regulation was enacted in Russia as early as $1997,{ }^{16}$ Gazprom has retained a large measure of de facto control over access to the UGSS through its monopolisation of data on capacity utilisation in the system, which has allowed it to argue that requested capacity is not always readily available or that the most direct route to consumers cannot always be used (thus increasing the cost to independent suppliers). It has also to date been reluctant to agree long-term access for NGP producers, restricting contracts to a maximum of three years, which has not been enough to encourage producers to develop new fields or to satisfy consumers about long-term security of supply.

Secondly, and perhaps more importantly, Gazprom has had a very significant say in the setting of the annual Gas Balance in Russia, through which projected gas production levels are set for one year ahead and also on a medium-term view in negotiation with the Russian Administration (TNK-BP, 2009, p. 214). The confidential nature of these negotiations and Gazprom's dominant position as a state-owned company and the major producer in Russia has effectively allowed it to control levels of NGP production to its own benefit.

Thirdly, the low level of regulated gas prices in Russia has meant that gas consumers have naturally preferred to buy gas from Gazprom ahead of the NGPs. Gazprom is mandated to sell a very large proportion of its gas sales in Russia at a price set annually by the Federal Tariff Service, and until recently this price has been well below the level at which NGPs were prepared to sell their gas (Henderson, 2010). For most of the post-Soviet era Gazprom has been making a loss on its domestic gas sales because of the low level of regulated prices, and as a result significant price increases have been introduced since 2000 and in 2007 the volume of regulated price sales was also fixed to ensure that Gazprom could gradually sell more gas at non-regulated prices (Burgansky, 2010, pp. 181-182). However, it has nevertheless been the case that until very recently NGP producers have been selling gas to domestic consumers at a premium to Gazprom's prices, thus naturally restricting their ability to compete.

\footnotetext{
${ }^{16}$ Government Resolution No.858, 14 ${ }^{\text {th }}$ July 1997, “On the Provision of Access of Independent Organisations to the Gas Transportation System of OJSC Gazprom”.
} 
Finally, there has been a natural reluctance for NGPs to compete directly with a state-owned company such as Gazprom, which not only has a dominant position in the gas industry but also has significant influence across the entire economic and political spectrum of Russia. As a result, even larger producers such as Novatek have sold a significant proportion of their gas directly to Gazprom at the wellhead (Novatek, 2012c, p. 13), only selling to end-consumers in a small number of regions sanctioned by Gazprom. Indeed some producers, such as LUKOIL, have taken a policy decision to sell all their gas straight to Gazprom in order to avoid all the issues of transport capacity, customer allocation and potential conflict, and this essentially defensive strategy has again naturally limited the growth of NGP output because it has made them subservient to Gazprom’s overall strategy.

However, a number of the constraints on the potential for NGP growth are now easing, and the increasing regulated domestic gas price in particular has played a major role in providing an extra incentive for new NGP gas sales. As mentioned above, the historically low level of the regulated gas price has meant that NGPs have traditionally had to sell their gas at a higher price than Gazprom in order to make a profit, meaning that in reality they have only been competing to sell into a narrow market of premium gas consumers who need more gas than they can receive under the regulated price regime (in effect any volumes above those that they were receiving at regulated prices in 2007). This market for "new gas" has been growing as demand in Russia has expanded by around $1.5 \%$ per annum over the past decade (Pirani, 2011), but nevertheless it has remained much smaller than the c.300bcma of gas that has been purchased at regulated prices.

Figure 9 demonstrates that this pricing anomaly has now ended, however, with the implication that the entire Russian gas market is effectively open for competition. The graph shows the average premium at which Novatek has been selling gas to Russian end-users since 2007 compared with the average Gazprom price to the same market. In 2007 Novatek was selling its gas at a $16 \%$ premium to the average Gazprom price, but as the regulated price has increased since then so the premium has fallen every year, to the point where in the first half of 2012 Novatek has for the first time sold its gas at a discount to Gazprom's regulated price, with the comparative prices being RR2652/mcm for Novatek versus RR2699/mcm for Gazprom. As a result it would now appear that Novatek, and by extension the remaining NGP sector, is in a position to compete for Gazprom's entire sales portfolio in Russia rather than just the premium segment which is prepared to pay higher prices for "new gas" as before. 
Figure 9: Novatek sales price to End Consumers in Russia compared to Gazprom sales price

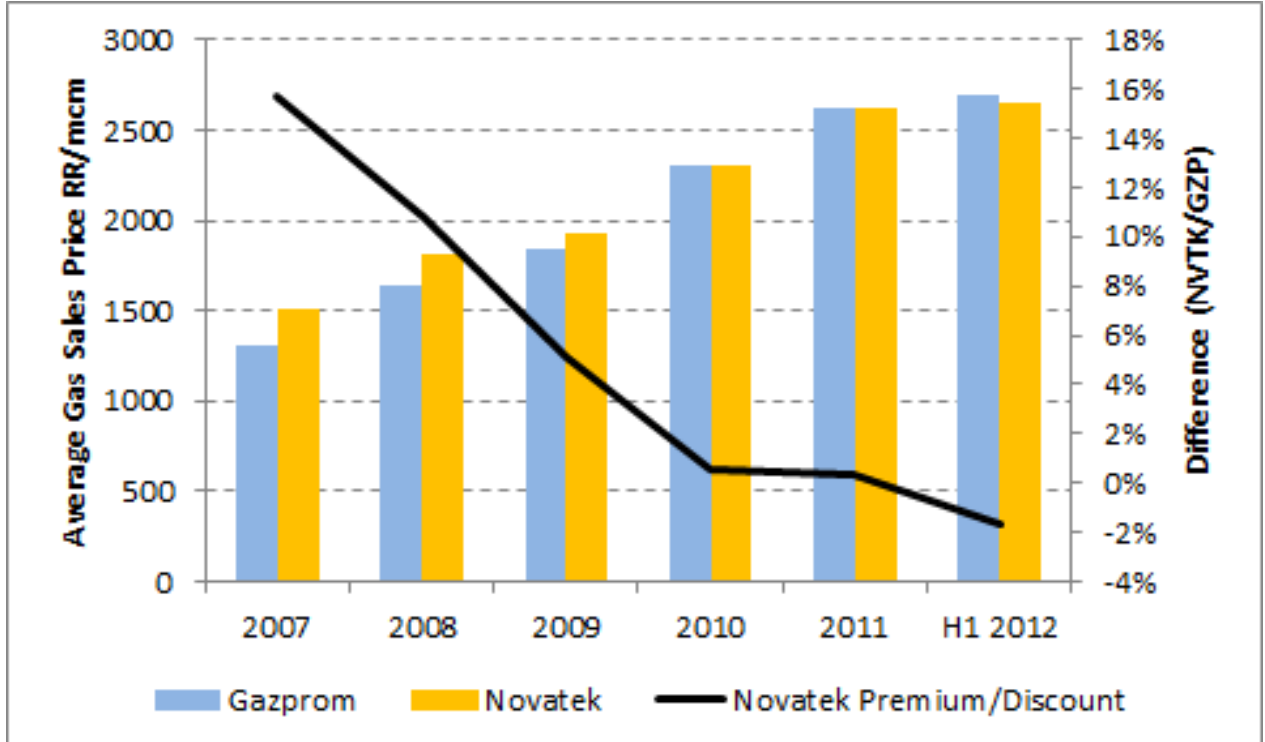

Source: Novatek and Gazprom Management Discussion and Analysis of Financial Results 2007-H1 2012

The fact that NGPs can now afford to compete with Gazprom at a price equivalent or at a discount to the regulated gas price in Russia is exemplified by the fact that Novatek's profitability does not appear to have been hampered by the decline in the premium it has been charging over Gazprom’s prices. Over the past five years Novatek’s EBITDA margin has been consistently above $45 \%$ while the company's net profit margin has been in the range $30 \%$ to $40 \%$ (see Figure 10 ) at a time when revenues have more than doubled and EBITDA has tripled (excluding exceptional items). As a result the company has demonstrated that it can very profitable to sell domestic gas in Russia, despite that fact that Gazprom claimed that it only managed to breakeven for the first time in its domestic business in 2009 (Gazprom, 2010, p. 36). 
Figure 10: Novatek’s EBITDA and Net Profit Margins (2008-2011)

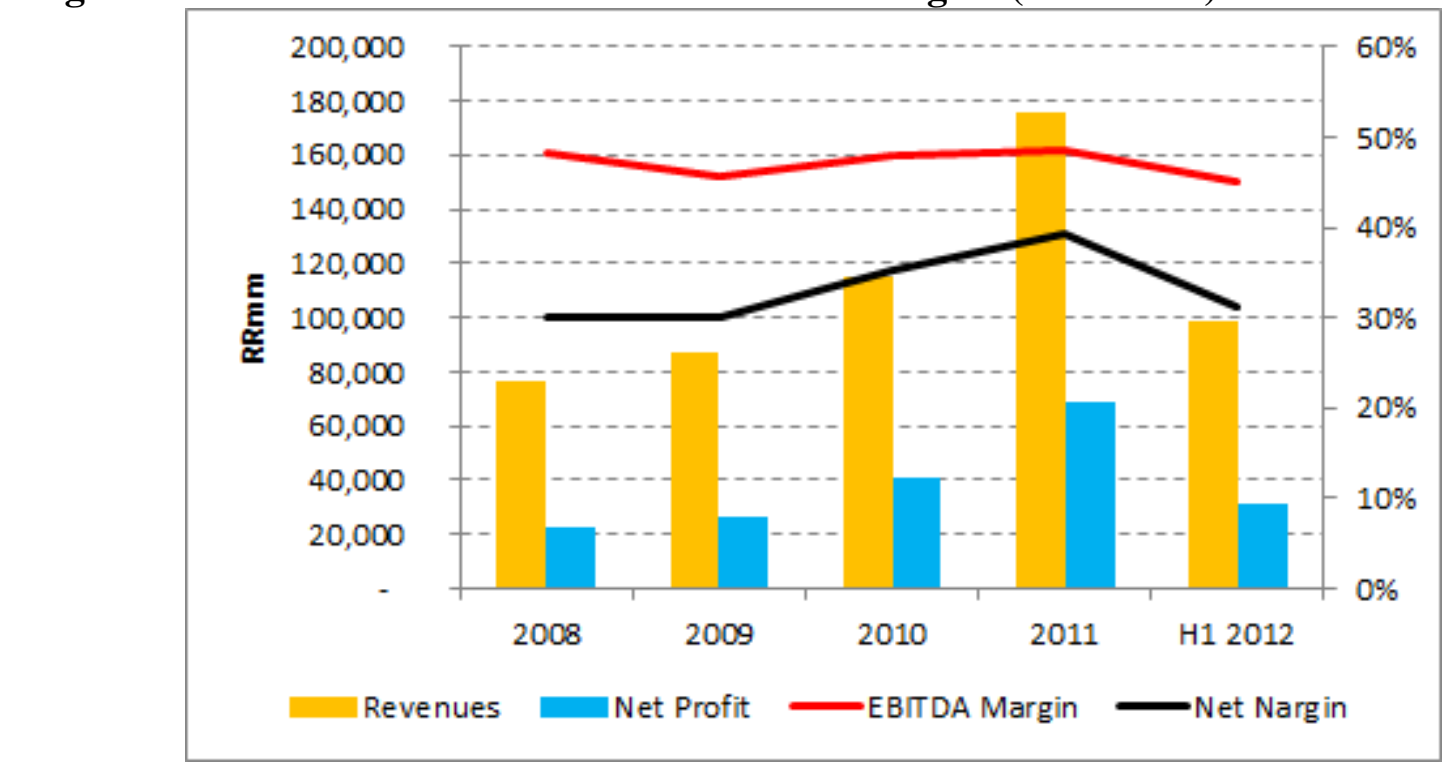

Source: Novatek Q2 2012 Quarterly Highlights

As discussed above, the benefits of generating revenues from condensate sales thanks to increased production of wet gas are one reason why the NGP sector has the opportunity to become increasingly competitive in Russia. Novatek is the prime example of this trend, but TNK-BP's (now Rosneft's) Rospan fields, ENI-Enel-GazpromNeft's Severenergia fields, the Yamal LNG project (Total and Novatek) and Wintershall's Achimgaz JV with Gazprom provide other examples of gas developments with associated liquids, and the trend is set to grow over the next decade. Gazprom itself estimates that the share of wet gas in the overall Russian gas portfolio will expand from 24\% in 2008 to more than 60\% by 2030 (Gazprom, 2010, p. 12). However, the NGP producers will not just be relying on the benefits of liquids production at a time of high oil prices to sustain their future gas production, as many of the companies also have significant gas assets close to existing infrastructure. This is particularly true of Rosneft, whose major Kharampur field has been awaiting development in the heart of West Siberia for five years, and of LUKOIL, which owns large gas fields both in West Siberia and in the south of Russia that are close to existing infrastructure and, in the case of the company's Caspian assets, consumers. Many of the smaller NGPs also own gas assets in the heartlands of the Russian gas sector and which could therefore be easily and cheaply exploited given the opportunity. 


\section{Government policy and support for NGP producers}

However, although higher domestic prices and the cost competitive nature of much of the NGP gas that could be made available in the short-to-medium term are encouraging an increasingly competitive outlook from the major NGP players, government support for any shift in the balance of the domestic gas market remains vital, especially because it involves consequences for a state-owned company, Gazprom, that is Russia's most profitable and economically significant individual company. ${ }^{17}$ As can be seen in Figure 11, the share of NGP production in Russia's total gas output has been rising throughout the 2000s, but it is really since the economic crisis in 2008/09 that it has become a very significant part of the Russian gas balance, reaching 25\% of total production in 2011.

\section{Figure 11: Share of NGP output in Russia's gas production}

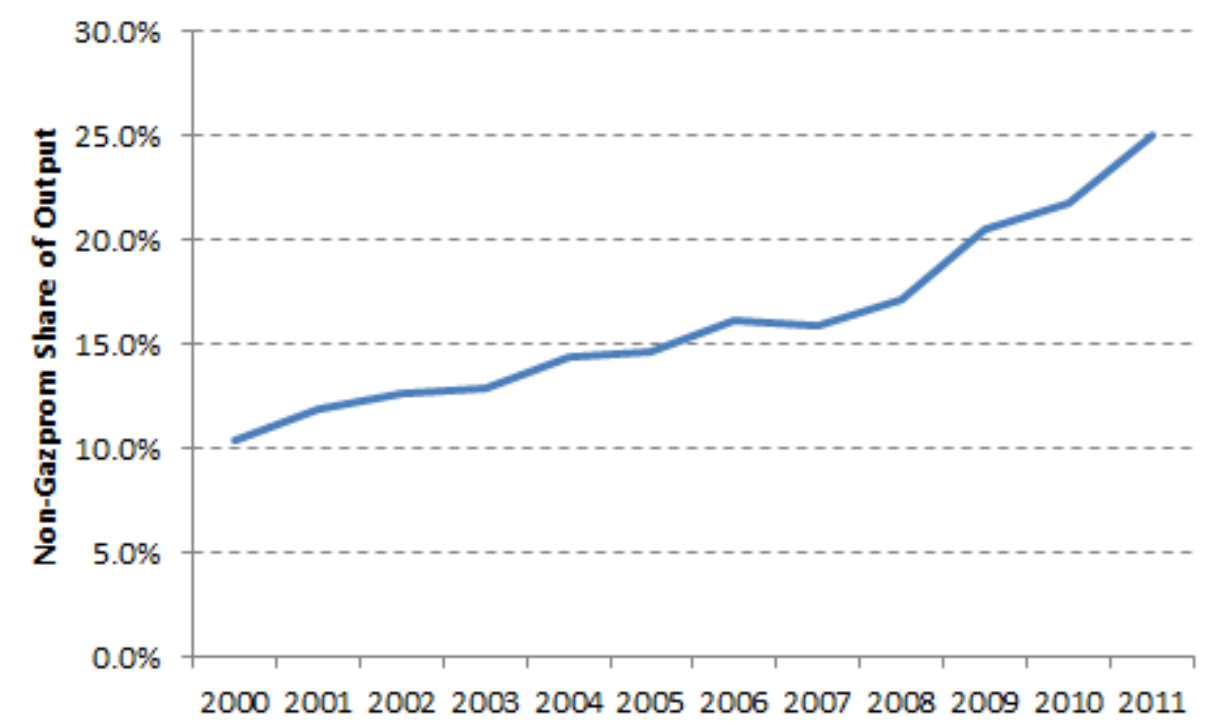

Source: Interfax. Ministry of Energy of Russian Federation

The acceleration in NGP market share growth has, perhaps not surprisingly, coincided with increasing political support for the sector, which began in January 2009 when then Prime Minister Vladimir Putin confirmed his views that NGPs should be given greater access to Gazprom's pipeline system. He stated on German television that “we are seeing it as our goal to provide our gas producers with more liberal access to Gazprom's pipeline system”"18 and confirmed this intention in May 2009 when he ordered the Federal Anti-Monopoly Commission to investigate accusations that Gazprom was blocking the implementation of several NGP contracts. ${ }^{19}$ He expanded his views later in the year at an investor conference

\footnotetext{
${ }^{17}$ Financial Times, 27 Sept 2012, “Gazprom crisis cast shadow over Putin”, London

${ }^{18}$ Interview on German TV network ARD on January $15^{\text {th }} 2009$

${ }^{19}$ Interfax, 29 May 2009, “Gazprom blocking contracts of several independent gas producers”, Moscow
} 
held by VTB Capital ${ }^{20}$ when he stated: "In Russia, like everywhere, we see the negative side of excess monopoly in one area or another, and gas is no different", citing "restraints on the growth of independent producers" as one of the main negatives of this situation, which the government would tackle by "aiming to provide equal access to gas infrastructure."21

The political rhetoric was increased in February 2010 when Putin urged Gazprom to take a more active role in developing supplies to industrial customers, warning the company that "Gazprom must treat the development of the infrastructure that helps provide the energy sector with gas as responsibly as possible. Otherwise independent producers will also be ready to make their contribution to the solution of these issues...If the company [Gazprom] itself proves unable to cope with all of these tasks it means we will have to involve other companies.”22 Not surprisingly other government ministers have backed up this view, with former Energy Minister Sergey Shmatko stating in March 2012: "We believe that we need to provide long-term rules of the game on the gas market that support growth of production by independent producers. [We need to offer] the opportunity to prolong previously received access to the gas transport system on a notification basis if there is an extension in relations between supplier and consumer."23

In addition to the rhetoric there are a number of other signs that a review of operations in the Russian gas sector is underway. Firstly, a presidential commission for the strategic development of the fuel and energy complex was set up in June 2012 following Putin's reelection as President of Russia in order to allow him to continue his direct oversight of the energy, and particularly gas, sector, despite the fact that a parallel structure already exists with the Russian government centred on the Ministry of Energy. ${ }^{24}$ Interestingly the presidential commission involves Igor Sechin, a close ally of Putin and the former Deputy Prime Minister with responsibility for Energy who has now left the government to take up the position of CEO of Rosneft. In this new role he sees it as a major goal "to optimize the [company] structure because Rosneft is growing very quickly. Besides that, now we are dealing with gas more, and a subdivision that works with gas will appear.” His position as secretary of the presidential energy commission will allow him to encourage development of the market in order that Rosneft can exploit the "new opportunities for the monetization of

\footnotetext{
20 "Russia Calling” Investor Conference hosted by VTB Capital, a Russian investment bank, in Moscow in September 2012

${ }^{21}$ Interfax, 29 Sept 2009, “Putin urges careful approach to gas market liberalisation”, Moscow

22 Prime Minister Putin quoted at a meeting of power generation companies in February 2010

${ }^{23}$ Interfax, 26 March 2012, "Rosneft, TNK-BP, Novatek to boost gas output over 30bcm in 3 years”, Moscow

${ }^{24}$ Moscow Times, 24 July 2012, "Why Dvorkovich and Sechin's Turf War Is Public", Moscow
} 
gas and the realization of Rosneft's strategic program for bringing significant reserves of gas into development" that were identified when the company finalised its gas JV with Itera in June 2012. ${ }^{25}$

Secondly, President Putin has now started to use the commission to start a review of the competitive position of the Russian gas sector and its relationship with the Russian economy. At a meeting held in October 2012 he demanded that Gazprom carry out a detailed review of trends in the global gas market, in particular in the light of the shale gas revolution in the US, and to report back to the commission on "the main principles of its gas export policy...[and how it can] increase the export potential and competitiveness of Russian energy resources...because the Russian economy depends upon its effectiveness."26 Furthermore Putin has also recently acknowledged issues surrounding Gazprom's efficiency and corruption issues at the company, stating at an investor conference in October 2012: "We are more and more often hearing complaints about how Gazprom does business, that there are corrupt elements... I am already aware of this and have standing orders given repeatedly to law enforcement bodies. If they dig something up, then God giving, that means they'll put somebody in prison”. ${ }^{27}$ Although these statements themselves do not specifically encourage NGP players, they nevertheless reinforce the view that Putin is keeping a very close eye on the gas sector and that the current status quo is at least under significant scrutiny.

Thirdly, and perhaps more relevantly for the short term development of the Russian gas market, Putin and other government ministers have endorsed the re-introduction of an exchange for trading gas, most likely located in St Petersburg. Discussion on this topic has been continuing for a number of years since the dissolution of a trial electronic trading system in 2008 (Burgansky, 2010), and has been confused by Gazprom’s desire to use its own trading platform for physical gas established by its subsidiary Mezhregiongaz rather than accept a separate commodity exchange. ${ }^{28}$ Nevertheless it is encouraging for NGPs that the opportunity for the development of a spot market of sorts is again being discussed by the

\footnotetext{
${ }^{25}$ Interfax, 8 June 2012, “Rosneft, Itera wrap up gas JV creation”, Moscow

${ }^{26}$ President Putin in introductory statement to the Presidential Energy Commission in October 2012, Moscow

${ }^{27}$ President Putin at VTB conference, quoted by Interfax, 2 Oct 2012, “Corrupt Gazprom officials, if there are any, should be caught, imprisoned", Moscow

${ }^{28}$ Interfax, 20 Nov 2012, "Energy Ministry backs gas trading on exchanges and electronic trading facilities", Moscow
} 
government, and that the platform for any exchange could be independent of Gazprom, further underlining the declining influence of the state-owned company. ${ }^{29}$

Finally, even the question of Gazprom's export monopoly appears to be open at least to discussion in a way that would have been unthinkable even two or three years ago. New Energy Minister Novak has acknowledged that the presidential commission could soon get round to the issue of the export monopoly, although he did caveat: "Some people say [Gazprom's monopoly] shouldn't be abolished, independent producers say it should. The problem can't be solved just like that, without analysis. Everything should be worked through. ${ }^{30}$ As if to reinforce this point the influential entrepreneur and co-owner of Novatek Gennady Timchenko openly questioned the need for Gazprom's export monopoly in an interview with Forbes magazine, ${ }^{31}$ and Rosneft CEO Igor Sechin, while defending the idea of a single export channel run by Gazprom, did not exclude the possibility of other companies achieving overseas sales under commission agreements with the export monopolist. ${ }^{32}$

However, while it is interesting that the key political figures are starting to advocate and support change in the Russian gas sector, there has been no overt implementation of specific new policies in this direction. Nevertheless, it is possible to argue that the increasingly firm application of existing policies and legislation provides more practical evidence that, without undue fanfare, new entrants are being encouraged in the gas sector. In particular, the implementation of third party access regulation has always been the most significant issue for NGPs, and as highlighted above was raised by Putin himself in 2009 as an issue to be investigated by the Anti-Monopoly Commission. This move by the then Prime Minister followed a call from Igor Sechin, in his role as Deputy Prime Minister responsible for Energy, for an investigation by the Federal Anti-Monopoly Commission into the third party access issue in 2008, ${ }^{33}$ and since then it has become increasingly clear that NGPs are now being supported in this area as physical capacity has opened up in the pipeline system and the courts have supported NGPs in a number of claims against Gazprom.

From a physical perspective, the decline in Gazprom's major fields in Nadym-Pur-Taz has meant that surplus pipeline capacity from West Siberia has gradually emerged over the past

\footnotetext{
${ }^{29}$ Interfax, 24 April 2012, "Russian govt. decides to establish exchange market for gas”, Moscow

${ }^{30}$ Interfax, 9 Oct 2012, "Russian gas market to be discussed at govt. meeting in October", Moscow

${ }^{31}$ Reuters, 29 Oct 2012, “Timchenko challenges Gazprom export monopoly - Forbes”, Moscow

32 Interfax, 23 Oct 2012, "Rosneft in favour of Gazprom keeping its export monopoly”, Moscow

33 IHS Report, 7 July 2008, "Deputy PM instructs Gazprom to ease pipeline access for Russian gas producers", Moscow
} 
three to five years, and with Gazprom's production focus now increasingly being turned to the Yamal peninsula, from where a new pipeline system has been built, it seems likely that the availability of ullage in the UGSS should remain for the foreseeable future. Indeed, as Loe (2012) has pointed out, some of her interviewees already argue that "third party access problems are a myth, not a reality, as long as gas producers meet the specific requirements for transport." ${ }^{34}$ Nevertheless, it has undoubtedly been the case that for some producers uncertainty about long-term access to the UGSS has been a disincentive to invest in high cost assets with a lengthy payback period, with TNK-BP's delay in the development of its Rospan asset being a prime example. However, two recent court cases brought by the Federal AntiMonopoly Service (FAS) against Gazprom appear to have confirmed that the third party access law is being implemented rigorously, providing practical encouragement to NGPs looking to sell gas to end-consumers in Russia. The details of both cases are published on the FAS web-site, ${ }^{35}$ with the first involving a small trader, GazEnergo-Alyanz (GE-A), which applied for short-term access to the UGSS in April 2009 as its existing transport contract expired, but whose application was not considered until August 2009, well beyond the 15 day limit for Gazprom to provide a response. The FAS found Gazprom guilty of negligence and of damaging the interests of GE-A, as its customers terminated gas purchase agreements, and this ruling was upheld by two Moscow Arbitration Courts and finally by the Federal Arbitration Court in Moscow in April 2011. ${ }^{36}$

The second case concerns another trader, Real-Gaz, who had concluded a contract with an end-consumer but was then refused access to the UGSS because Gazprom believed that the consumer was already well-enough supplied and because Gazprom could not guarantee supplies to the relevant gas distribution station, neither of which are legal justifications for refusing access. Real-Gaz therefore filed a complaint to the FAS who found Gazprom guilty of abusing its dominant market position in February 2012, with the decision being confirmed by the Moscow Arbitration Court in July 2012. ${ }^{37}$ In reporting on the case the FAS also noted that it had examined dozens of similar cases and had proposed a draft resolution to the government on improving independent access to the gas transport system that has now been supported by all interested parties and just awaits government approval. As a result it would appear that on the key issue of third party pipeline access the existing law is being enacted

\footnotetext{
${ }^{34}$ Quote in Loe (2012) from Mark Gyetvay, CFO of Novatek

${ }^{35}$ http://fas.gov.ru/fas-in-press/

${ }^{36} \mathrm{http} / / /$ fas.gov.ru/fas-in-press/fas-in-press_32743.html

${ }^{37}$ http://fas.gov.ru/fas-in-press/fas-in-press_34936.html
} 
relatively rigorously, and may be further enhanced, providing practical support to those companies looking to increase their gas sales to end-consumers in Russia.

\section{A series of long-term contracts has been signed in 2012}

The real proof, of course, is when long-term gas contracts are signed and honoured, and in this respect the clearest evidence of the evolution of the Russian gas market in 2012 has been provided by the increasing list of new deals that have been signed between NGPs and new end-user customers. The first signs of significant competition between domestic suppliers actually emerged in 2009, at the time when Prime Minister Putin first became active on the topic, when Novatek signed a contract to supply Inter RAO, a Russian power trader, and its generating subsidiary OGK-1 with 65bcm of gas between 2010 and $2015 .{ }^{38}$ In concluding the deal Novatek displaced gas supplies to Inter RAO from Gazprom, Itera and TNK-BP, despite the fact that the former supposedly had a contract that did not expire until 2012. Furthermore, the basis for the deal was that Novatek was offering its gas at the regulated gas price (and perhaps even at a discount) and was also offering better supply terms than Gazprom and its other competitors. $^{39}$ Specifically Novatek has since confirmed that this involves a more flexible attitude towards the take-or-pay arrangements within its contracts, with sales being arranged on a monthly basis without the constraint of an overall minimum annual contract quantity. These terms have also been reflected in Novatek's subsequent long-term contracts and are seen by the company as one if its main competitive advantages in its gas marketing business. ${ }^{40}$

Table 1 lists the Novatek-Inter RAO contract and the major new contracts that have been signed between NGPs and Russian industrial and power consumers since June 2012. As can be seen, Novatek remains the leading player in the field, but a number of the Russian oil companies have also been active, in particular Rosneft.

\footnotetext{
${ }^{38}$ Reuters, 5 Nov 2009, “Novatek \$6bn supply deal threatens Gazprom contract”, Moscow

${ }^{39}$ Interfax, 16 Nov 2009, “Inter RAO says Novatek offering better gas supply terms than other producers”, Moscow

${ }^{40}$ Interfax, 17 July 2012, “Novatek signs 11.5 year gas supply contracts with two Mechel enterprises”, Moscow
} 
Table 1: NGP gas contracts with domestic Russian consumers

\begin{tabular}{|l|l|c|c|c|l||}
\hline Seller & Buyer & $\begin{array}{c}\text { Volume } \\
b c m\end{array}$ & $\begin{array}{c}\text { Duration } \\
\text { years }\end{array}$ & Announced & Comment \\
\hline Novatek & Inter RAO & 7.7 & 6 & Nov-09 & Direct sales to Inter RAO for 2010-2015 \\
Novatek & OGK-1 & 57 & 6 & Nov-09 & Sales to Inter RAO subsidiary for 2010-2015 \\
Novatek & MMK & 50 & 10 & Jun-12 & c.5 bcma+ from 2013 \\
LUKOIL & E.On Russia & 2.24 & 10 & Jun-12 & Supply to Yaivinskaya GRES \\
Novatek & Mechel & 17 & 11.5 & Jul-12 & Part of new marketing business in Chelyabinsk \\
Novatek & E.On Russia & 150 & 15 & Aug-12 & 4 contracts to supply E.On power assets in Russia \\
Novatek & Fortum & 30 & 15 & Aug-12 & Contract to supply Nyaganskaya GRES \\
Novatek & Uralchem & 8 & 5 & Sep-12 & 1.6 bcma from 2013-2017 \\
Rosneft & E.On Russia & 23 & 3 & Sep-12 & Supply to Surgutskaya GRES \\
SurgutNG & E.On Russia & na & 3 & Sep-12 & Supply to Surgutskaya GRES \\
Novatek & Severstal & 12 & 5 & Oct-12 & Contract to run from Jan 2013 \\
Rosneft & Inter RAO & 875 & 25 & Nov-12 & Supply to Inter RAO power assets from 2016-2040 \\
Novatek & Mosenergo & 27 & 3 & Dec-12 & Supply to Gazprom power subsidiary in Moscow \\
TNK-BP & TGK-5 & est. $15 \mathrm{bcm}$ & 17 & Dec-12 & Supply to IES subsidiary from 2013-2030 \\
TNK-BP & TGK-7 & est. 20bcm & 15 & Dec-12 & Supply to IES subsidiary from 2015-2030 \\
TNK-BP & TGK-9 & est. 20bcm & 17 & Dec-12 & Supply to IES subsidiary from 2013-2030 \\
\hline
\end{tabular}

Source: Interfax, Company Press Releases

Novatek has been particularly dynamic in the marketing of its gas since the acquisition of a Gazprom subsidiary “Gazprom Mezhregiongaz Chelyabinsk” in December 2011. ${ }^{41}$ Novatek CEO Leonid Mikhelson acknowledged that in an era of higher domestic gas prices and therefore growing availability of domestic supply due to increasing interest in the market from potential new players it needed to be able to "increase market penetration in key gas consuming regions within the domestic market”. ${ }^{42}$ As a direct result of this acquisition the new contracts with MMK and Mechel shown in Table 1 were signed for 10 and 11.5 years respectively, directly replacing Gazprom as the main supplier. In line with this strategy to sign up long-term customers Novatek has also signed new contracts with Uralchem, Severstal, Fortum and E.On Russia, in each case displacing Gazprom and securing a market for its own growing gas production. Finally, and perhaps most indicatively, Novatek has signed a three year supply contract with Mosenergo, a Gazprom power subsidiary, to supply it with 27bcm of gas in the period 2013-2015, effectively supply one third of its gas needs. ${ }^{43}$ This contract is a clear indication of the fact that all gas consumers in Russia, even companies owned by the country's state-owned gas company, now seem to be seeking out the best deals for gas supply rather than relying on the previously dominant Gazprom.

The example of E.On as a consumer is particularly interesting because it has been the most aggressive in replacing Gazprom as its supplier with a series of contracts with NGPs, and has also traded the NGPs themselves off against each other. In August 2012 E.On became the

\footnotetext{
${ }^{41}$ Novatek press release, 1 Dec 2011, “Novatek acquires regional gas distributor”, Moscow

42 Ibid

${ }^{43}$ Interfax, 5 Dec 2012, “Novatek could supply a third of Mosenergo’s gas”, Moscow
} 
first power company to announce that it was completely shifting its gas supply contracts away from Gazprom, which had been its major supplier in 2011, to NGPs, and it also readjusted the balance of supply at a number of its power stations, after stating "in negotiations with potential suppliers of gas, the best terms were offered by Novatek." ${ }^{44}$ As can be seen in Table 1, Novatek now has a long-term 15-year contract to supply E.On Russia assets across the country while Surgutneftegas (and Rosneft) have much shorter and smaller contracts to supply Surgutskaya GRES as a result of the renegotiations. On the same day that it announced its new deal with E.On Novatek also revealed a new contract to supply Fortum's power assets in the Chelyabinsk region, ${ }^{45}$ further confirming the benefits of its newlyacquired marketing company in the region.

LUKOIL has also signed a small contract with E.On, to supply its generating plant at Yaivinskaya, but in general the company has adopted a much more passive strategy in marketing its natural and associated gas. In West Siberia, where LUKOIL produces around 8bcma from its Nakhodkinskaya field, the company has adopted the policy of selling all the gas at the well-head to Gazprom at prices close to the regulated price on a netback basis, and it has recently "re-affirmed its commitment to the agreements reached on the main principles of the strategic partnership, which are based on strict observance of mutual interests in the gas supply sphere.”46 In the south of Russia LUKOIL has adopted a slightly more pro-active stance, buying power assets in the Southern Federal District (TGK-8) which will consume gas from the company's North Caspian fields as they increase production over the next decade, thus essentially providing a fully integrated gas to power chain that has been facilitated by the liberalisation of the Russian electricity market rather than direct competition in the gas market (LUKOIL, 2012c, p. 79). TNK-BP, meanwhile, has also formed a link with Gazprom, via a joint venture called the Novo-Urengoy gas company, ${ }^{47}$ and has now signed direct contracts with three power companies, shown in the table above, via this $\mathrm{JV}^{48}$ It is interesting to note, though, that the three TGK assets are owned by Renova, the conglomerate owned by joint-TNK-BP owner Viktor Vekselberg, indicating that TNK-BP, like LUKOIL is exploiting the opportunity for sales to related parties. Nevertheless, TNK-BP has also

\footnotetext{
44 Interfax, 23 Aug 2012, “E.On Russia to drop Gazprom for Novatek in 2013”, Moscow

45 Novatek press release, 28 Aug 2012, “Novatek concludes long-term gas supply contracts”, Moscow

${ }^{46}$ Interfax, 13 Sept 2012, “Gazprom, LUKOIL chiefs re-affirm observance of mutual interests in gas supply sphere”, Moscow

${ }^{47}$ Interfax, 9 Oct 2012, “Gazprom will resume buying gas from independents based on market”, Moscow

${ }^{48}$ Interfax Oil and Gas Daily, 5 Dec 2012, "TNK-BP to supply gas to IES gencos from Novy Urengoi Gas Co. resources", Moscow
} 
developed an active marketing department based around its gas assets in the Orenburg region, targeting new customers in European Russia with its competitive local gas supplies.

Until 2012 Rosneft had also been relatively inactive in the marketing of its gas, but the last 11 months have seen a dramatic shift in the company's strategy, mainly catalysed by the formation of a joint venture with Itera in February $2012^{49}$ and the subsequent purchase of a $51 \%$ interest in the company. ${ }^{50}$ Rosneft then announced its goal to increase gas sales to c.75bcma by 2017 and to 100bcma shortly thereafter, and confirmed this plan not only in the purchase of TNK-BP but more importantly through the signing of the largest NGP gas contract to date, with Inter RAO, on $1^{\text {st }}$ November 2012. This contract not only provides Rosneft with an average of 35bcma of sales for 25 years, is also the largest example of competition for customers between NGPs, as Rosneft will displace Novatek from one of its largest customers when its existing contract ends in 2015. As Novatek has been selling gas to Inter RAO at the regulated gas price it can be assumed that Rosneft must be offering a discount to this level, again emphasizing that money can be made below Gazprom's established price and also confirming Rosneft's strong ambition, as stated by company CEO Igor Sechin, to “develop [our] gas programme. It’s very interesting work for us”. ${ }^{51}$

Possible competition in the gas export market?

While the evidence supporting the thesis that new entrants are causing evolution in the domestic gas market is mounting, a smaller body of emerging examples suggests that Gazprom's export monopoly is also coming under some threat. Although, as noted above, noone is discussing the breaking of the "single export channel" model, Rosneft CEO Sechin has at least mentioned the possibility of export deals under an agency arrangement while Novatek and LUKOIL are now beginning the first non-Gazprom sales of gas to customers outside Russia. Novatek is clearly being encouraged by its main shareholders to explore markets outside Russia, and LNG from the company’s Yamal LNG project is being targeted at both the European and Asian markets (Novatek, 2012a, p. 20), albeit under an agency agreement with Gazprom which will see the state-owned company act as an intermediary but will still allow Novatek to market its own gas in export markets. Perhaps even more proactively, Novatek has recently signed a gas sales agreement with German subsidiary EnBW to sell 2bcma from 2012 for 10 years, sourcing the gas from European hubs at gas market related

\footnotetext{
${ }^{49}$ Interfax, 28 Feb 2012, "Rosneft, Itera agree to jointly develop Russian gas assets”, Moscow

${ }^{50}$ Interfax, 11 April 2012, "FAS clears Rosneft to buy 51\% of Itera”, Moscow

${ }^{51}$ Interfax, 1 Nov 2012, "Rosneft signs 25-year deal to supply Inter RAO with gas from 2016”, Moscow
} 
prices. $^{52}$ Although the deal has been portrayed as Novatek establishing a market position prior to the marketing of its LNG from Yamal, it provides clear competition with Gazprom (EnBW could have been a Gazprom customer) and endorses a Russian company selling gas at European hub prices (in contrast to Gazprom's stance on oil-linked prices). Furthermore, it would not be a surprise to see Novatek arguing for access to Russian piped gas exports in the near future once it confirms its ability to operate in Europe and demonstrates the oddity of a Russian company selling non-Russian gas to a German company.

Meanwhile LUKOIL is already competing more indirectly with Gazprom in China, as it has begun to export gas from its fields in Uzbekistan at a time when Gazprom itself is still struggling to agree a sales agreement with CNPC to export gas from East Siberia. ${ }^{53}$ LUKOIL claims: "We have a pipeline project, with very good netbacks, supplying China," and the company plans to increase its output in Uzbekistan to 19bcma over the next few years. ${ }^{54}$ The majority of this gas is expected to be exported via the new Central Asia pipeline to China, and although its gas is not a direct threat to Gazprom's export monopoly from Russia it is nevertheless part of the Central Asian gas competition that is currently allowing the Chinese to enhance their bargaining position in relation to Gazprom's proposed sales in the East.

\section{Conclusions}

Overall, then, it would appear that NGPs have the ambition, the resources, the emerging political support, both verbally and practically, and the marketing ability to provide a significant challenge to Gazprom in Russia, and possibly in the longer term overseas. The NGP market share of supply in Russia has been increasing rapidly, in particular since 2009, and it would seem that the gas which NGPs have available for sale is competitively priced relative to Gazprom's regulated price (especially as the regulated price has risen significantly over the past decade) and relative to Gazprom's increasing cost of supply as it develops remoter fields on the Yamal peninsula. Looking forward, it would seem that Novatek's prognosis of NGP production of 300bcm by 2020 is achievable, with the major constraint likely to be the outlook for demand in Russia and Europe rather than any political backlash in support of Gazprom. Indeed, there would even appear to be a risk that in a weak demand scenario Gazprom's production could itself stagnate at the levels seen during the 2008/09

\footnotetext{
${ }^{52}$ Reuters, 14 Aug 2012, "Russia’s Novatek confirms long term gas supply deal with Germany’s EnBW" Moscow

${ }^{53}$ Bloomberg, 2 March 2012, “LUKOIL beats Gazprom’s Monopoly to China with Uzbek gas supplies”, London

${ }^{54}$ Ibid
} 
crisis at below 500bcma, or even fall sharply towards 400bcma if demand goes into decline as a result of increased energy efficiency in Russia.

Indeed, evidence for Gazprom concern on this issue was made very clear in September 2012 when it made a short-lived decision "to suspend its acquisition of NGP gas under current contracts due to unstable demand for gas on the domestic market”. ${ }^{55}$ Although the decision was reversed the next day, with Gazprom claiming that purchases were proceeding as normal, it is easy to see how such a choice could be forced on the company. In 2011 Gazprom bought 42bcm of gas from NGPs for re-sale, producing and selling 515bcm of its own gas. In 2012 the plan had been for Gazprom to produce 529bcm, but by September its production was actually almost $19 \mathrm{bcm}$ behind the 2011 schedule, ${ }^{56}$ implying that it was almost $40 \mathrm{bcm}$ behind the 2012 target and set to dip below 500bcm again this year. The key drivers for this outlook are lower sales in Western Europe, where exports are set to drop to around 140bcm compared to $150 \mathrm{bcm}$ in $2011,{ }^{57}$ declining CIS exports, with sales to Ukraine likely to be down by 15bcm in 2012 compared to 2011 and greater competition in the domestic market. As a result, it would be natural for Gazprom to respond by refusing to buy gas from companies that are becoming its serious competitors in Russia.

From a Russian government perspective, the conclusions to be drawn from the increasing competition in the Russian gas market are also potentially significant. Firstly, it would appear that support for NGP producers is starting to produce a more cost-efficient industry that can provide consumers with gas at below the regulated gas price in significant volumes. This is clearly a benefit to the Russian economy as well as to the well-connected entrepreneurs who are investors in the NGP producers and are keen to see them increase market share. However, it does raise some interesting questions for the Russian Administration.

The first is how long should the regulated price continue to exist and for how many more years can mandated price increases be imposed? The fact the NGP producers are already selling at a discount to the regulated price suggests that the answer to both questions is "not very long”, although it should be noted that the discounted NGP contracts with endconsumers are related to the regulated price themselves and so only offer a discount on the new price each year. Nevertheless, most players in the market assume that the $15 \%$ growth

\footnotetext{
${ }^{55}$ Interfax, 10 Sept 2012, “Gazprom will resume buying gas from independents based on market”, Moscow 56 ibid

${ }^{57}$ Interfax, 17 Oct 2012, “Gap between spot prices, Gazprom contract prices narrowing in EU - Deutsche Bank", Moscow
} 
imposed in 2012 and set for 2013 and 2014 is unlikely to go on beyond 2015 at the latest, at which point the domestic price will have reached c. $\$ 150 / \mathrm{mcm}$, a level that is likely to provide a market price that can balance the interests of producers and consumers in Russia.

The second question is then how the government can manage the increasing tax burden that it wants to impose on the gas sector? The gas royalty $\operatorname{tax}^{58}$ is set to rise sharply over the next 4 years to take account of rising domestic gas prices, with the levels for Gazprom and NGPs due to be set in March 2013. The level of this tax will however have to be carefully managed if it is to provide adequate budget funds without undermining the economics of gas production in Russia if market conditions suggest that gas prices cannot be increased much further. Nevertheless, it will be easier to raise taxes at lower gas prices from more efficient and competitive NGP producers than from a state company that is less profitable in the domestic market and relies on export sales to boost its revenues and cashflow.

One final question concerns whether the competitiveness of Russian gas in export markets is best maintained through Gazprom holding onto its export monopoly or whether NGP gas should be introduced into the Russian gas export portfolio. Russia’s position as a gas exporter to Europe is being undermined by increased flows of LNG to the continent and by Gazprom's intransigence over oil-linked prices. This is in itself driven both by the relatively high cost of its supplies and by the fact that it does not want to give up the premium offered by the fact that oil-linked prices are higher than hub-based prices in Europe. One solution would be the introduction of lower cost NGP gas into the Russian export portfolio and, as suggested in earlier paper (Henderson, 2011) this does not necessarily mean the end of a single export channel from Russia, but could imply a gas export pool (including NGP gas) from which a single exporter could select the most competitive gas for sale overseas in order to maintain Russia's competitive position. The fact that Novatek has been allowed to make a first NGP mark in Europe (for which it must surely have received Kremlin approval) suggests that the issue is at least being debated at the highest levels in Russia.

In final conclusion, therefore, it would seem that the arrival of new entrants into the Russian gas market is creating the conditions if not for a revolution catalysed by a dramatic reform process then perhaps for a gradual evolution based upon the commercial realities facing the Russian gas industry today. The process is currently being led by two major NGPs, Novatek and Rosneft, followed by a series of smaller domestic and foreign players, who are

\footnotetext{
${ }^{58}$ Natural Resource Extraction Tax (NRET), which is charged on each mcm of gas produced
} 
increasingly adopting more aggressive marketing strategies to ensure that they create a market for their expanding gas production. Given the potential for excess gas supply in the Russian market over the next decade this would appear to be a very sound strategy, but it is one that is a very new development for a sector that has been dominated by one monopolistic player for so long. The fact that this dominant player, the state-controlled Gazprom, has yet to demonstrate any significant response to this increased competitive threat implies that it would not be a surprise if the diverse group of NGP actors were to account for more than one third of Russian production, over half of all domestic gas sales and perhaps even a significant share of export sales by 2020. 


\section{Bibliography}

Alekperov, V. (2011). LUKOIL: Building Value Through Innovation. Moscow: LUKOIL.

Alekperov, V. (2012b). Third Decade of Evolution: New Challenges, New Opportunities. Moscow: LUKOIL.

Burgansky, A. (2010). Oil and Gas Yearrbook 2010. Moscow: Renaissance Capital.

Gazprom. (2010). Gaining Momentum. Moscow: Gazprom.

Gazprom. (2012a). Bond Prospectus. Moscow: Gazprom.

Gazprom. (2012b). Scale Does Matter. Moscow: Gazprom.

Gazprom Neft. (2011). Full Year Results 2010. Moscow: Gazprom Neft.

Henderson, J. (2010). Non-Gazprom Gas Producers in Russia. Oxford: Oxford Institute for Energy Studies.

Henderson, J. (2011). Domestic Gas Prices in Russia: Towards Export Netback? Oxford: Oxford Institute for Energy Studies.

IEA. (2011). World Energy Outlook, 2011. Paris: IEA.

Interfax. (2012). Russia's Gas Industry (2012). Moscow: Interfax.

ITERA. (2009). Russian Independent Gas Company. Moscow: ITERA.

Loe, J. P. (2012). Russian Gas Reform Under Putin III: Stakeholder Perspectives On The New Commercial Reality. Oslo: Russ'Casp.

LUKOIL. (2012a). 2012-2021 Strategic Development Programme. Moscow: LUKOIL.

LUKOIL. (2012b). Fact Book 2012. Moscow: LUKOIL.

LUKOIL. (2012c). Fact Book 2012. Moscow: LUKOIL.

LUKOIL. (2012d). LUKOIL Databook 2012. Moscow: LUKOIL.

Maximov, O. (2012). Russian Oil and Gas - The Blushing Bride: Unnatural Gas. Moscow: Troika Dialog.

Novatek. (2011). Focus on Growth. Moscow: Novatek.

Novatek. (2012a). Russia's Natural Gas Frontiers. Moscow: Novatek.

Novatek. (2012b). Harnessing the Energy of the Far North: Annual Report 2011. Moscow: Novatek. 
Novatek. (2012c). FY 2012 Results Conference Call. Moscow: Novatek.

Pirani, S. (2011). Elusive Potential: Natural Gas Consumption in the CIS and the Quest for Efficiency. Oxford: Oxford Institute for Energy Studies.

Rosneft. (2006). Analyst Presentation. Moscow: Rosneft.

Rosneft. (2008). 2008 Financial Results Presentation. Moscow: Rosneft.

Rosneft. (2012a). Analysts' Databaook 2011. Moscow: Rosneft.

Rosneft. (2012b). Non-Deal Roadshow. Moscow: Rosneft.

TNK-BP. (2009). Bond Prospectus 2009. Moscow: TNK-BP Finance SA.

TNK-BP. (2012). Company Strategy. Retrieved June 12, 2012, from TNK-BP Corporate Web Site: http://www.tnk-bp.ru/en/company/strategy/ 